\title{
Mining Diamonds in THE Canadian Arctic: The Diavik Mine
}

James E. Shigley, Russell Shor, Pedro Padua, Christopher M. Breeding, Steven B. Shirey, and Douglas Ashbury

The Diavik mine, located in the Archean-age Slave geologic province in northern Canada, is one of the world's preeminent sources of gem diamonds. Since mining operations began in 2003, it has produced over 100 million carats of diamonds. This article will review the discovery, development, and operation of the mine, which is situated in a remote subarctic setting in the Northwest Territories. Four kimberlite pipes occur in close proximity - three are being exploited, while the fourth will be brought into production in 2018. Diavik is now expected to operate through 2024; upon closure, the equipment, buildings, and infrastructure will be removed and the land returned as closely as possible to its original condition.

C anada is the world's fourth-largest diamond producer, with most of that output coming from one area near Lac de Gras in the Northwest Territories. The discovery of kimberlite pipes there in the early 1990s led to the development of several major mines. Diamond-bearing kimberlite deposits that can be mined economically are noteworthy, since only about 50 such occurrences have been found worldwide since the 1870s, mainly in Australia, Angola, Canada, Russia, and South Africa (Janse, 2007). As of mid-2016, Canada has three active mines: Ekati and Diavik (figure 1), located about $30 \mathrm{~km}$ from each other in the Northwest Territories (figure 2), and the Victor mine in northern Ontario. Snap Lake, recently placed in a care and maintenance status, lies within $80 \mathrm{~km}$ of Ekati and Diavik. Two other Canadian mines are under development: Gahcho Kué in the Northwest Territories and Renard in Quebec. Figures from the Kimberley Process (www.kimberleyprocess.com/en/canada) show that Canada produced 11.6 million carats of rough diamonds in 2015, valued at US $\$ 1.675$ billion.

See end of article for About the Authors and Acknowledgments.

Gems \& Gemologr, Vol. 52, No. 2, pp. 104-131,

http://dx.doi.org/10.5741/GEMS.52.2.104

(C) 2016 Gemological Institute of America
This article will discuss the discovery, development, and operation of Diavik, one of the richest diamond mines in the world. Over several days in late June 2015, the authors visited the site to capture photographs and gather information on the mining operations. The visit involved tours of the open pit and underground workings, the processing and recovery plant, and the facility in Yellowknife where diamonds are cleaned and sorted for distribution (figure 3). In this article, we focus on the unique engineering challenges in developing the Diavik mine and recovering diamonds from beneath a lake in a harsh subarctic environment, all while doing so in a way that protects the environment, ensures worker safety, and respects the cultural traditions of the local indigenous peoples.

\section{DIAMOND EXPLORATION IN CANADA}

Canada is the world's second-largest country in terms of land area, but until the 1990s it was not considered an important source of gemstones. During the preceding century, alluvial diamonds were occasionally found in scattered locations across southern Canada and the northeastern United States (Hausel, 1995). Their association with glacial sediments in the Great Lakes region led Hobbs (1899) to propose that the diamonds had been transported by the southward 


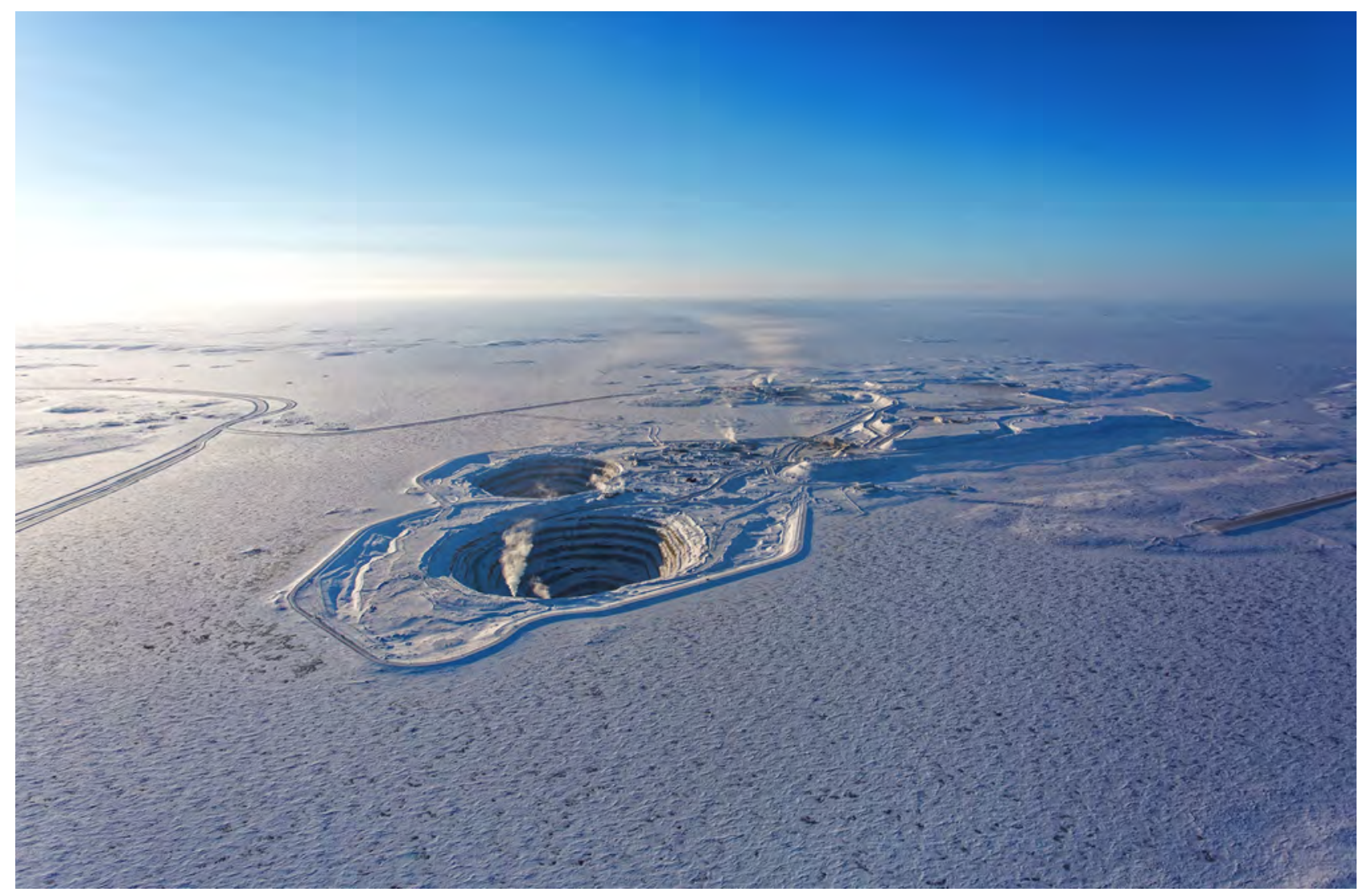

Figure 1. The Diavik diamond mine, shown here in February 2015, is located on a small island in Lac de Gras, approximately $300 \mathrm{~km}$ northeast of Yellowknife and $220 \mathrm{~km}$ south of the Arctic Circle, in a remote region of Canada's Northwest Territories. Photo courtesy of Diavik Diamond Mine.

movements of glaciers (which covered large portions of Canada during the Pleistocene epoch, from 2.5 million until about 12,000 years ago) from unknown source rocks in the area near Hudson Bay (see also Bell, 1906).

Kjarsgaard and Levinson (2002) presented a comprehensive review of the discovery and development of Canada's diamond mines through the 1990s. Although the north-central areas of the country were known to be underlain by ancient rocks of Archean age- the rocks that also host diamondiferous kimberlites in southern Africa and elsewhere-there was little effort on the part of large mining companies to search for diamonds in the Slave craton (Pell, 1995; Carlson et al., 1999). Along with the vast expanse of territory, the very small target area presented by kimberlite pipes, and the cost of search efforts over a period of years, those authors suggested two additional reasons for the lack of diamond exploration programs in northern Canada. The first was logistical: the re- moteness of the area, much of it covered by water, and the harsh climate that limited the field season for exploration. The second reason was the glacial

Figure 2. This regional map of northern Canada shows the locations of Diavik and other diamond mining operations.

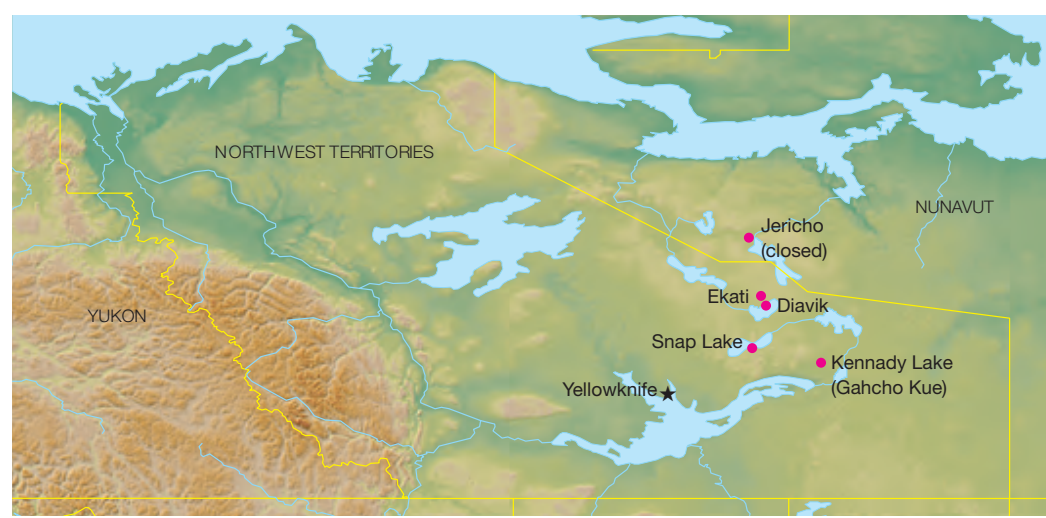


dispersal of the contents of exposed kimberlite pipes by the movement of ice sheets away from the original pipe locations. New geological exploration techniques, similar to those being used in Siberia, were needed to search for diamondiferous kimberlites in this type of terrain, which is much different from that of southern Africa (McClenaghan and Kjarsgaard, 2001).

According to Kjarsgaard and Levinson (2002), the modern era of diamond exploration in Canada began in the early 1960s with the traditional search for the diamond "indicator minerals" (such as red Cr-rich pyrope garnet, green $\mathrm{Cr}$-diopside, green olivine, black ilmenite and black Cr-spinel). These minerals, which weather out of kimberlites but are retained as colorful grains in alluvial sediments in far greater abundance than the similarly resistant but much rarer diamonds (Gurney, 1984; McClenaghan, 2005; Shirey and Shigley, 2013). The discovery of these minerals signaled the presence of kimberlites in a particular area, and chemical analysis of them could distinguish those pipes that might contain diamonds. In Canada, the search for these minerals would ultimately involve years of lonely work in a nearly uninhabited and inhospitable region (Krajick, 2001).

The topography of northern Canada has been sig- nificantly influenced by periods of glaciation in the geologic past. The land is relatively flat to slightly undulating, marked by low barren hills and shallow bodies of water. In this setting, diamond prospectors had come to believe that sampling glacial eskers (narrow, sinuous ridges composed of sand and gravel sediments deposited by streams from melting glaciers) for indicator minerals might prove successful in locating kimberlites. This had been the case with searching for similar minerals in stream sediments in nonglaciated terrains (McClenaghan et al., 2000; McClenaghan and Kjarsgaard, 2001). Initial target areas included northern Ontario and portions of Quebec, followed by a shift in exploration toward the north and west of the country.

Diamond prospectors who previously found indicator minerals along the Mackenzie River Valley in the Northwest Territories realized that the westward movement of glaciers had transported these minerals from source rocks near the center of the continent. In the early 1980s, improved airborne geophysical survey methods for locating small-target kimberlite pipes over a wide area, combined with a better understanding of how to check sediments from both glacial moraines and eskers, led to preliminary diamond discoveries in various parts of the country.

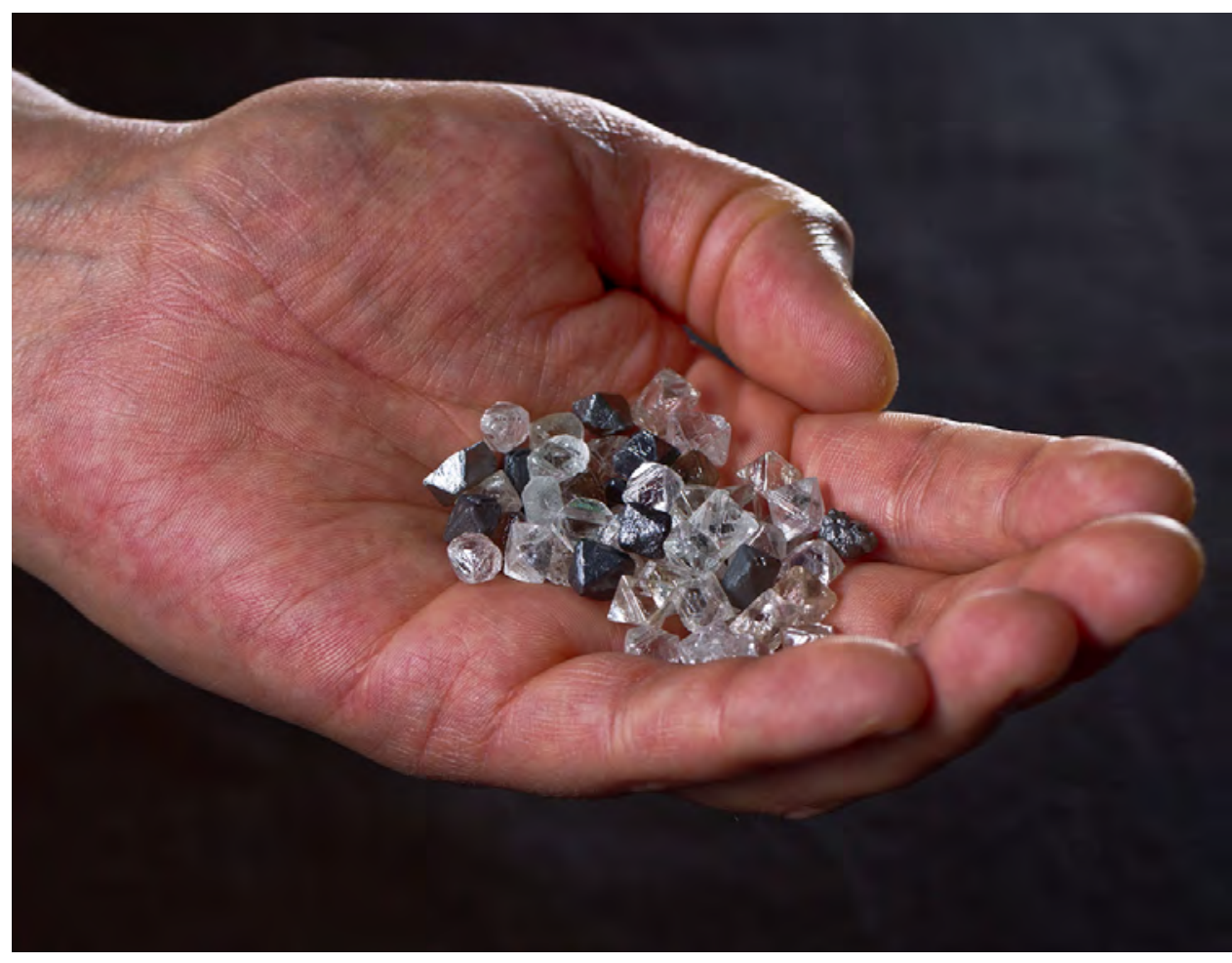

Figure 3. This selection of rough diamonds is typical of Diavik's production. Photo courtesy of Diavik

Diamond Mine. 
After these initial finds, however, the idea of a more extensive search for diamonds in northern Canada was met with skepticism. Initial exploration efforts involved several major mining companies, but the search was primarily undertaken by smaller companies and even groups of individual prospectors.

In April 1990, after a decade of exploration across an east-west distance of $1,200 \mathrm{~km}$ in the Northwest Territories, came Chuck Fipke's discovery of a bright green Cr-diopside crystal on a ridge at Point Lake, a small, circular crater-like lake just north of Lac de Gras. As this mineral does not survive travel far from its source rock, he concluded that it had come from a kimberlite pipe in the immediate vicinity. This led Fipke and his partner in Dia Met Minerals, fellow geologist Dr. Stewart Blusson, to stake a claim. Years later this area would become part of the Ekati mine (Fipke et al., 1995). Additional heavy mineral samples collected north of Point Lake confirmed the presence of a kimberlite pipe. Partnering with BHP Minerals, a large international mining company based in Australia, they obtained drill core samples from the pipe to better evaluate its mineral content and structure.

\section{In Brief}

- Diavik in northern Canada is one of the world's most important diamond mines, with production to date of more than 100 million carats.

- Mining takes place year-round in a remote and hostile subarctic environment.

- Before open-pit mining could begin, retention dikes had to be built to enclose the workings, which were below the water level of Lac de Gras.

- Mining is expected to continue through 2024, after which all infrastructure must be removed and the site returned as closely as possible to its original condition.

In November 1991, BHP announced that $59 \mathrm{~kg}$ of kimberlite core samples from the site contained 81 small gem-quality diamonds, and that the company would spend up to $\$ 500$ million to develop a mine. Over the next 12 months, this stunning development triggered the biggest land rush in Canadian history, as mining companies and individual prospectors staked claims over some 22,000 square kilometers in the north-central part of the country (Krajick, 1994, 2001; Boyd, 2006).

Over the past 25 years, exploration efforts have identified more than 500 kimberlite pipes throughout
Canada, with more than $50 \%$ containing traces of diamonds. Most of these occurrences are located in the Lac de Gras region near the center of the Slave craton (Carlson et al., 1999). Few of these pipes are directly exposed at the surface; most are buried beneath bodies of water, and they have been revealed by geophysical and field sampling techniques. Because kimberlites weather and decompose faster than much older surrounding rocks, the pipes often occur in topographic depressions beneath lakes. By the end of 1994, a total of 39 kimberlites had been identified in the Lac de Gras area, including what would become the country's first diamond mine: Ekati, which opened in the fall of 1998. Because these kimberlite pipes were located in an ecologically sensitive portion of northern Canada, the mining ventures had to undergo an extensive environmental, economic, and social review involving several government agencies and local indigenous communities before proceeding with development.

\section{DISCOVERY AND HISTORY OF DIAVIK}

By early 1992, Aber Diamond Corporation had staked a claim to 3,250 square kilometers in the Diavik area. The company began a helicopter-borne magnetic survey (in partnership with Kennecott Canada, the exploration arm of Rio Tinto) to identify target locations as prospective kimberlite pipes (Carlson et al., 1999; Graham et al., 1999). A Yellowknife-based exploration company (Covello, Bryan \& Associates) was hired for the prospecting activities. Ground, gravity, and other geophysical measurements were also made to confirm that the targets were kimberlites, and to better delineate the size of potential pipes. Samples collected from glacial till, streams, and beaches around these locations were analyzed for indicator minerals. When potential targets were detected, they were ranked in order of priority for additional study based on their geophysical characteristics and proximity to the indicator minerals. Core drilling of the most promising sites was then carried out to determine the lateral extent of the pipe and its micro-diamond content.

Indicator minerals were first discovered on the Diavik property in 1994, near what was then designated as the A21 anomaly, but the decision was made to first core-drill the nearby anomaly that later became the A154 (South) pipe. This drilling produced a section of kimberlite core that broke open to reveal a $2.5 \mathrm{ct}$ diamond crystal (Graham et al., 1999; Tupper and Neamtz, 2002). Considering the rarity of diamonds in kimberlite pipes, to encounter such a large crystal in a random core section was remarkable. In 1995, the adjacent A418 pipe was evaluated for its diamond po- 
tential. Drilling revealed that the geomagnetic anomalies were small, steeply inclined, semicircular volcanic pipes that became narrower with depth.

By 1995, four diamond-bearing kimberlite pipes had been located-all beneath the waters of Lac de Gras. The pipes are adjacent to the lake shoreline and lie within $4 \mathrm{~km}$ of one another. Additional core drilling was carried out to carefully delineate the sizes and shapes of the pipes, and their potential diamond grade was estimated from analyzing the drill cores. Between 1996 and 1997, the initial pipesA154 (which was later found to be two adjacent pipes) and A418-were accessed by several largediameter (approximately $15 \mathrm{~cm}$ ) holes, core drilling to depths of about 250 meters, and then by underground tunnels excavated 150 meters beneath Lac de Gras. From these activities, 5,937 tonnes of kimberlite ore were recovered from the A154 South and A418 pipes. Evaluation of this bulk sample was critical to determining whether the pipes contained enough high-quality diamonds for mining to be economical. Some of the recovered ore was analyzed at the company's pilot processing plant in Yellowknife, and the rest was split into two portions for separate evaluation at both the Yellowknife plant and the nearby Ekati mine. In 1998, analysis of 21,013 carats of diamonds (one-third of which were gem quality) recovered from the bulk ore sample provided the first evidence of the mine's economic potential.

Earlier in 1995, hydrological and geotechnical studies were begun to assist in the conceptual design and development of both the open-pit and planned underground mining operations. These studies have continued to the present day.

Despite the environmental and engineering challenges for large-scale mining in this remote region, Rio Tinto and Dominion Diamond Corp. (formerly Aber) established a formal joint venture in 1999 to develop the property. Rio Tinto managed and operated the mine through a wholly owned subsidiary, Yellowknife-based Diavik Diamond Mines Inc. Diamond production would be divided between the two organizations, with each independently marketing its own share.

In addition to examining the economic feasibility of operating a diamond mine under arctic conditions, the developers conducted environmental risk analysis between 1997 and 2000. A scientific assessment of all aspects of the regional environment provided a baseline to measure the impact of the subsequent construction and operation of the mine. Agreements also needed to be signed with the five First Nations- the Lutsel K'e Dene First Nation, the Yellowknives Dene First Nation, the Tlicho Government, the Kitikmeot Inuit Association, and the North Slave Metis Alliance-which had inhabited the area for centuries. These groups sought the protection of land and lakes and a share of the economic benefits from mining. In 2000, formal permission was granted to the joint venture to begin mine construction. This included an environmental agreement with the Canadian government, and a socioeconomic monitoring agreement with the government of the Northwest Territories.

Between 2000 and 2003, approximately CAD $\$ 1.3$ billion was spent building the mine infrastructure, one of the largest capital investments undertaken in the history of Canadian mining. This included a plant to process the kimberlite ore and recover the diamonds, office and accommodation buildings for several hundred staff, utilities (electric power and heat generation, water supply, and wastewater treatment), bulk fuel and explosive storage, a maintenance shop, a containment area for storing the processed kimberlite, and an airstrip capable of handling cargo and passenger aircraft. Development of the site occurred in a relatively uninhabited arctic tundra setting - the closest indigenous community was $190 \mathrm{~km}$ to the southwest. Everything needed to construct and maintain the site had to be flown in from Yellowknife or trucked over an ice road during wintertime. Transition from a construction project to active diamond production commenced in January 2003, with an expected mine lifetime of about 16-22 years. Sales of the first rough diamonds began in the summer of that year.

In 2006 and 2007, another group of bulk kimberlite samples was collected underground at each of the three pipes (A154, A418, and A21) to determine underground mining conditions, to compare the impact of drill and blast mining versus machine mining on diamond value, and to provide about 15,000 carats from each pipe for additional estimations of rough diamond values. With the exception of the data on diamonds from A21, these 2006-2007 estimates have been superseded by more recent information obtained from actual production parcels from A154 $(117,000$ and 118,000 carats in May 2013) and A418 (186,000 carats in May 2012). Since 2003, the mine has yielded 100 million carats of rough diamonds, with the largest crystal found to date weighing 187.7 ct (figure 4). Named the "Diavik Foxfire," it was produced between May 31 and June 6, 2015 (see the Lab Notes section of this issue, pp. 188-189). Previously, the largest gem-quality diamond recovered weighed $151 \mathrm{ct}$. 


\section{GEOLOGICAL SETTING}

This kimberlite province, discovered in 1991 and measuring about $400 \times 750 \mathrm{~km}$, is a portion of the Slave craton, a region of the continental lithospheric plate (also known as the Canadian Precambrian Shield) that has remained geologically stable since Archean times 2.5 to 4 billion years ago (Pell, 1997; Bleeker, 2002; Davis et al., 2003; Canil, 2008; see boxes $\mathrm{A}$ and $\mathrm{B}$ and figure 5 ). In this region, the rocks that compose the ancient crust are exposed at the surface by glaciation. The craton consists of granites and gneisses, with younger volcanic and metasedimentary rocks deposited on them. It sits above a mantle "keel" (a downward-protruding thickened portion of the lithosphere) where relatively low heatflow and reducing conditions have remained suitable for diamond formation and preservation for an extended period of geologic time (Shirey and Shigley, 2013). Explosive kimberlite magma eruptions rising through this keel zone brought diamonds to the crust. This is a typical setting for kimberlite pipes in Archean cratonic rocks worldwide.

Subsequent to kimberlite pipe emplacement, this portion of Canada was covered by a glacial ice sheet that culminated about 20,000 years ago. As stated above, this glaciation removed much of the topography of the area, including the upper portions of the kimberlite pipes. On East Island, where the Diavik mine is located, the kimberlite pipes are hosted in approximately 2.5-billion-year-old Archean granitic host rocks as well as some younger metasediments. Several Proterozoic diabase dikes cut through zones of structural weakness in these granitic rocks-these same zones may have been where exploding kimberlite magmas broke through to the surface.

Kimberlite pipes are the near-surface conduits of kimberlite volcanoes. As no such eruption has ever been observed, the geological understanding of these events is based almost entirely on observations of the pipes' complex vertical structure obtained from drill core sections or exposed during underground mining, and from petrographic analysis of rocks found within the pipes (Moss et al., 2008). As in many other kimberlites worldwide, a complete understanding of the magma eruption process is often hindered by subsequent erosion, which removes important upper sections of a pipe.

More than 400 kimberlite pipes are now known in the Lac de Gras area (W. Boyd, pers. comm., 2016). They are distributed along a northwest-trending axis extending more than $120 \mathrm{~km}$. Only a few are economic to mine for diamonds. The Diavik mine lies

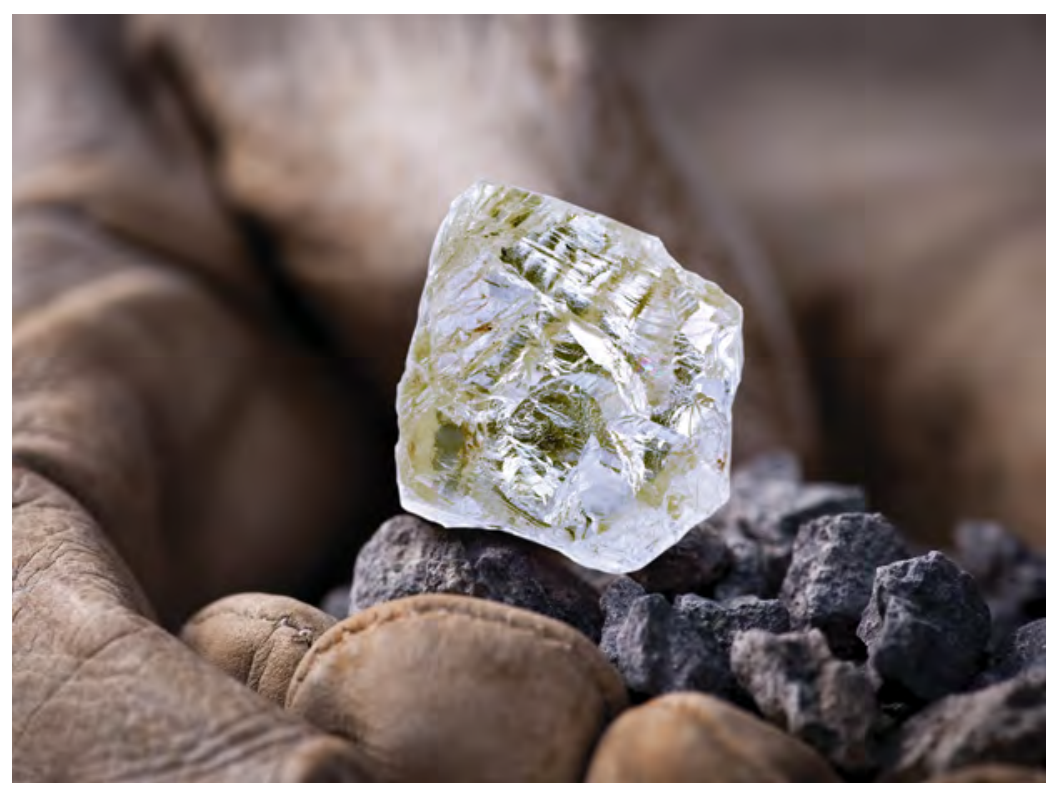

Figure 4. The 187.7 ct "Diavik Foxfire," discovered in spring 2015, is the largest gem-quality rough diamond found to date at the mine. Photo courtesy of Rio Tinto Diamonds.

near the center of the Slave craton. The geology of the four kimberlite pipes on the mine property is now well understood based on field studies conducted over the past two decades (Graham et al., 1999; Bryan and Bonner, 2003). Kimberlites at the mine are interpreted as representing coherent pyroclastic and volcaniclastic types of igneous rocks, and the pipe emplacement has been dated at $55 \pm 5$ million years ago, during the Eocene epoch (Graham et al., 1999). The pipes are up to 20,000 square meters at the surface, and they extend down to depths of at least 600 meters. Each has a different mixture of kimberlite types and country rock. Field studies of the A154 pipe by Moss et al. (2008) revealed a poorly sorted massive volcaniclastic kimberlite overlain by a better-sorted stratified volcaniclastic kimberlite containing variable proportions of consolidated mud and, at the top of the sequence, a graded pyroclastic kimberlite. The pipes are capped by several meters of glacial till, a thin layer of lacustrine sediments, and 15-20 meters of lake water. Moss et al. (2008) proposed a six-stage explosive eruption model for the A154 pipe:

1. Initial kimberlite eruption and excavation of the pipe to form a vertical pipe beneath a surface crater

2. Collapse of the pyroclastic gas cloud from above, and partial infilling of the upper portion of the pipe with massive kimberlite from below 


\section{Box A: The Slave Craton: An Ancient Remnant of Earth's Eariy Crust}

Seismically stable geological areas on Earth are known as cratons. These vestiges of ancient rock are the rarest, smallest, and oldest remnants of continental crust and immediately underlying 150-200 km of mantle (together known as the continental lithosphere). The Diavik mine lies in the middle of the Slave craton, which derives its name from the Great Slave Lake at its southern border. An exciting feature of the Diavik kimberlites, besides their abundance of diamonds, is that the kimberlite punctures and carries deeply derived pieces of the mantle from Earth's ancient past. The geological history preserved in the Slave craton offers a fascinating record, one that can be read from the complicated surface geology and especially from the deep mantle-derived rock samples brought up within the kimberlite.

Like other cratons (e.g., the Superior in Canada, the Kaapvaal in South Africa, or the Pilbara in Australia), the Slave craton is a complicated collage of different continental terranes created at different times and forced together over more than two billion years. The surface geology reveals the different ages of these units, and how they fit together like puzzle pieces. The vertical sampling of diamonds and mantle and crustal rocks by kimberlite that is then erupted to the surface becomes an invaluable tool to peer through the younger crustal rocks, which have a different surface geology from those at 30 to $150 \mathrm{~km}$ depths. With enough kimberlites and enough diamonds made available for study from mining operations, a vertical cross section of the craton can even be constructed (figure B-1).

At the surface of the Slave craton, the oldest rocks, some ranging in age up to 4.2 billion years, are exposed in the Acasta Gneiss Complex (AGC) on the far west side of the craton and in a north-south belt of gneisses known as the Central Slave Basement Complex (CSBC) in the center. Within these ancient complexes themselves, almost 1.4 billion years of geological evolution can be measured by radiometric dating methods. To the east of the CSBC, the surface rocks are all much younger, more granitic, and clearly related to the modern process of plate tectonic subduction that operated from the craton's eastern side about 2.5 billion years ago (Bleeker, 2002). Surprisingly, the diamondiferous kimberlites in the Slave craton have erupted through the craton east of the CSBC-coming clearly through parts of the craton that are dominated by younger rocks (most typically 2.5 billion years). Because the diamonds in the Diavik and other kimberlites are much older (up to 3.5 billion years) and similarly old mantle xenoliths occur in the kimberlites, the deep mantle keel must reside some $100 \mathrm{~km}$ below younger crust. The surface geology of the Slave craton, therefore, is an asymmetrical geological construct whose depths are known because of diamondiferous kimberlite eruptions.
3. Flows of debris from the surrounding crater walls and further infilling of the pipe, leading to the formation of the stratified kimberlite

4. Alteration of rocks within the crater by hot circulating fluids originating from groundwater interacting with the underlying kimberlite magma

5. Deposition of sediments in the upper portions of the crater, which now lie beneath a lake

6. Deposition of pyroclastic kimberlite in the crater by material ejected from adjacent kimberlite eruptions

At Lac de Gras, glaciation removed the top portions of the pipes. When exposed at the surface, kimberlites weather and decompose, becoming softer than the surrounding country rocks. With the retreat of the glaciers, the pipe locations often became depressions in the land surface, which filled with water to become lakes. The lakes at pipe locations are generally deeper than those formed by just glacial action.

Careful documentation of the different types of kimberlite (and other rocks) within a pipe is important because these factors can exert some control over the size and abundance of the diamonds, and on the processing of the material as kimberlite ore. This typically involves analyzing hundreds of ore samples.

\section{LOCATION AND ACCESS}

The Diavik mine is located at $64^{\circ} 29^{\prime} 46^{\prime \prime} \mathrm{N}$ and $110^{\circ} 16^{\prime} 24^{\prime \prime} \mathrm{W}$, on a small island in Lac de Gras about $300 \mathrm{~km}$ northeast of Yellowknife (the capital of the Northwest Territories), and $220 \mathrm{~km}$ south of the Arctic Circle. The mine is situated in a continuous permafrost zone $100 \mathrm{~km}$ north of the tree line (the latitude above which trees cannot survive the cold temperatures). The permafrost layer extends from two meters below the surface down to a depth of about 250 meters. The bedrock consists of glacially eroded granite that is covered in many places by glacial till. The till is composed of sand, gravel, cobbles, and boulders in varying proportions in a rock flour matrix. Near the lake shorelines, the finer material has been washed out, leaving mainly boulders. Beneath the lakes, the till is overlain by several meters of fine sediment. 


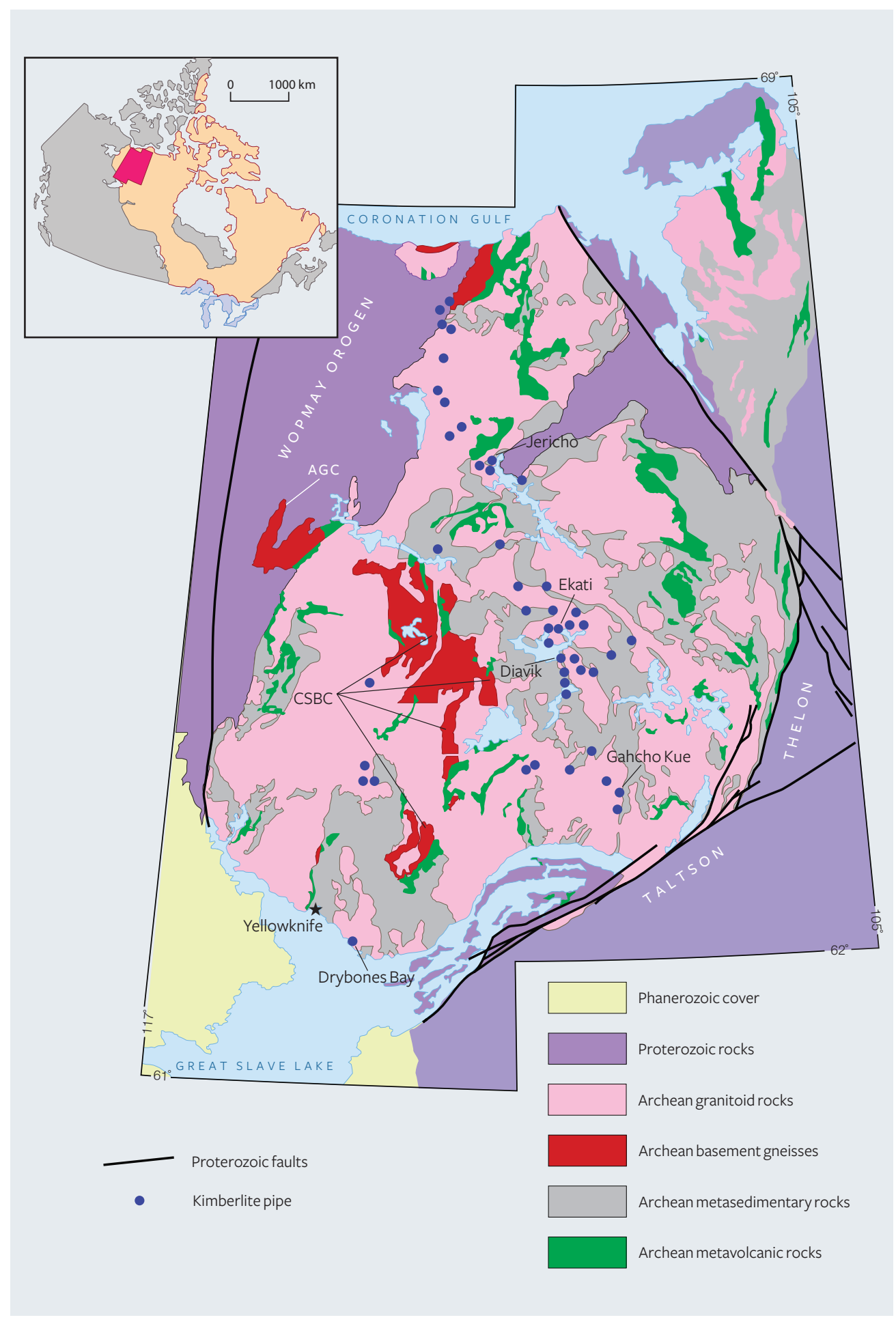

Figure 5. This simplified regional geological map shows the major rock units within the Slave Structural Province. Note that the basement gneisses of the Acasta Gneiss Complex (AGC) and the Central Slave Basement Complex (CSBC)—shown for both in red-contain some of the oldest rocks on Earth (up to 4.2 billion years) and that the Diavik mine is found to the east in much younger Archean rock (2.5-2.7 billion years). Yet we know that Diavik and the neighboring Ekati mine contain diamonds as old as 3.3-3.5 billion years. Thus they are found in old mantle at depths that might be related to the old surface rock to the east. See the cross section in box B. Modified from Bleeker (2002) and Helmstaedt (2009).

Summers at the site are short and cool, while the winters are long and extremely cold. In winter it is not unusual to have weeks with temperatures between $-35^{\circ} \mathrm{C}$ and $-40^{\circ} \mathrm{C}$, with frequent strong winds making these temperatures feel even colder. Snow may fall in any month of the year, but it normally occurs between October and April. The region receives only about $300 \mathrm{~mm}$ of precipitation per year, mainly in the form of snow, so it can be considered an arctic semidesert. Daylight ranges from about four 


\section{Box B: Ages of the Diavik Diamonds and Relationship to the Slave Craton}

The kimberlite magmas at Diavik intruded 55 million years ago and are thus much younger than the Archean craton. The kimberlites are the transporting mechanism for the much older diamonds and indicator minerals that formed deep within the mantle of the craton. These diamonds are xenocrysts in the kimberlite, as are the indicator minerals. Age relations have been established through geochronology, which uses radioactively decaying isotopes of elements such as rhenium and uranium to measure the age of the kimberlite, the mantle rocks that are the source of indicator minerals, and mineral inclusions in the diamonds. These relationships have been well studied from samples provided by Diavik mining operations. Through radiometric age-dating methods on sulfide mineral inclusions (chiefly the long-lived radioactive decay of rhenium to osmium) in otherwise gemquality diamonds, some of the oldest diamonds ever formed (3.3 to 3.5 billion years old) have been found in Diavik and its nearby counterpart, the Ekati mine (Westerlund et al., 2006; Aulbach et al., 2009). But age dating also shows that diamond formation in this portion of the deep mantle keel has been episodic and occurred in pulses that extend to as recently as 1.8 billion years ago. Any Diavik diamond in a ring will be at least one-third as old as the earth itself, and possibly three-quarters of its age.

An interesting and perhaps unique feature of Diavik and other Slave craton diamonds is their direct connection to the deep mantle conductors that trace the starting material to form diamond. Electrical sounding methods in geophysics, known as "magnetotellurics," deployed on the scale of the entire craton can detect connected electrical pathways between the nonconductive mantle minerals. This occurs along grain boundaries in the mantle rock. Carbon in the form of soft, smearable graphite can provide an electrically conductive pathway if it occurs in high enough concentrations. The outline of the conductive region at depth in the mantle almost perfectly encompasses the occurrence of diamondiferous kimberlites at the surface-thereby supporting a possible link between the carbon content of the deep mantle keel and diamond crystallization (Jones et al., 2003).

Another interesting feature of Diavik diamonds is the high proportion of "coated" crystals-gem-quality diamonds that have been overgrown with younger cloudy rims. These rims are cloudy because of abundant microinclusions of fluid whose composition is often salty or even briny. A recent study has shown that these rims represent a much more recent growth phase of diamond in the deep mantle keel, perhaps as young as 0.2 to 0.4 billion years (Weiss et al., 2015). This age is so recent that it can be related to known plate tectonic reconstructions, offering evidence of the subduction of seawater below and into the mantle keel by the underthrusting of a seawater-containing oceanic slab, more than $1,000 \mathrm{~km}$ east of where seawater is found. While seawater subduction is a well-known geological process, direct examples are rare and poorly studied. The Slave craton cross section (figure B-1) shows that a similar form of more ancient underthrusting occurred 1.8 billion years ago.

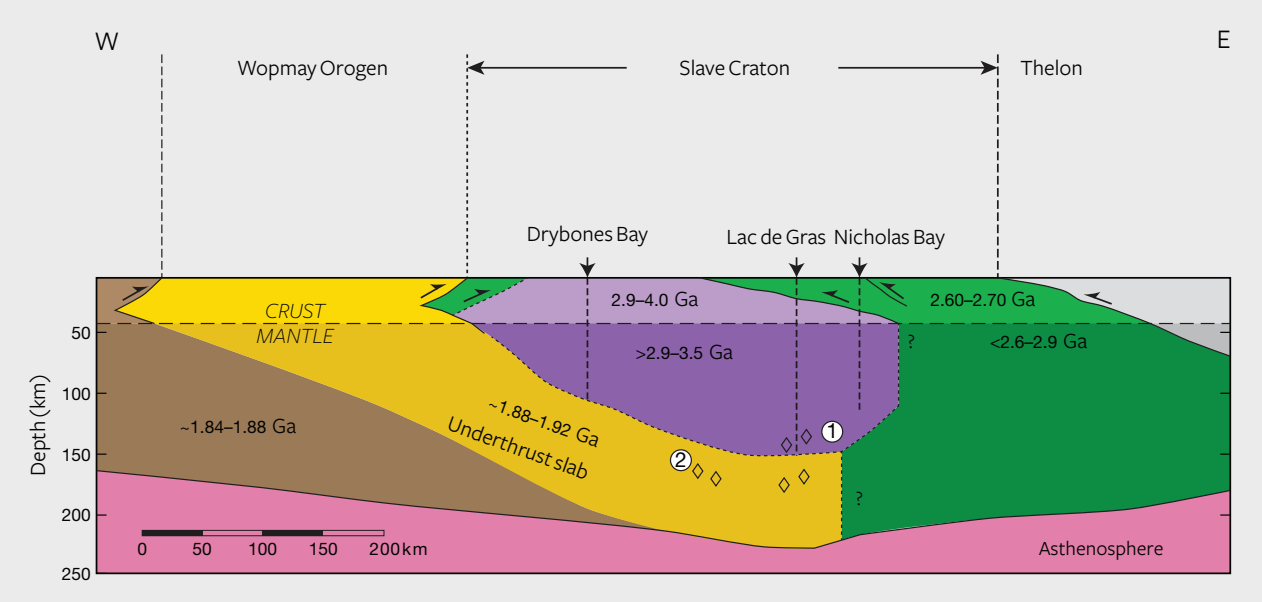

(1) Older generations of diamond in cratonic root or "keel"
(2) Younger generations of diamonds derived from carbon in underthrust slab
Figure B-1. Cross section of the Slave craton, constructed from surface geology, geophysics, and samples (mantle rock and diamond) provided by kimberlite eruptions and mining operations. Much of the detailed structure and age information between 30 and $250 \mathrm{~km}$ depths is only possible because suites of diamonds have been analyzed. Simplified from Helmstaedt (2009). hours per day in winter to as much as 20 hours per day in summer. Throughout most of the year, the mine can only be reached by air. For a brief time in the winter, an ice road provides vehicle access for thousands 
of tons of equipment, supplies, and fuel (box C). There is no regular road network in this part of Canada.

\section{MINE DESIGN}

The fact that the four kimberlite pipes were located beneath Lac de Gras (figure 6) posed an engineering challenge if the pipes were to be exploited. The option of accessing and mining the pipes underground from an onshore portal tunnel was ultimately rejected because it would require leaving too much valuable kimberlite ore in place for structural support directly beneath the lake bed. Therefore, a traditional open-pit approach was chosen to remove the kimberlite from the upper portions of the pipes. However, this would require the construction of specially designed dikes surrounding the pipes to allow the open-pit mining of ore bodies that would otherwise be underwater. This required dredging of the lake, placing several million tons of crushed rock into the lake to create the dikes themselves, anchoring the dikes to the bedrock, transferring fish from the enclosed areas back into the lake, and removing several million cubic meters of water from the enclosed areas. Particular challenges included building the dikes without direct access to the bedrock beneath the lake, working during winter months of intense cold and extended darkness when the lake surface would be frozen, preventing debris from contaminating the lake, the use of local material for dike construction (blasted and crushed granite taken in stages from the open-pit locations), and a heavy reliance on an indigenous community workforce with no experience in heavy civil construction/Olive et al., 2004).

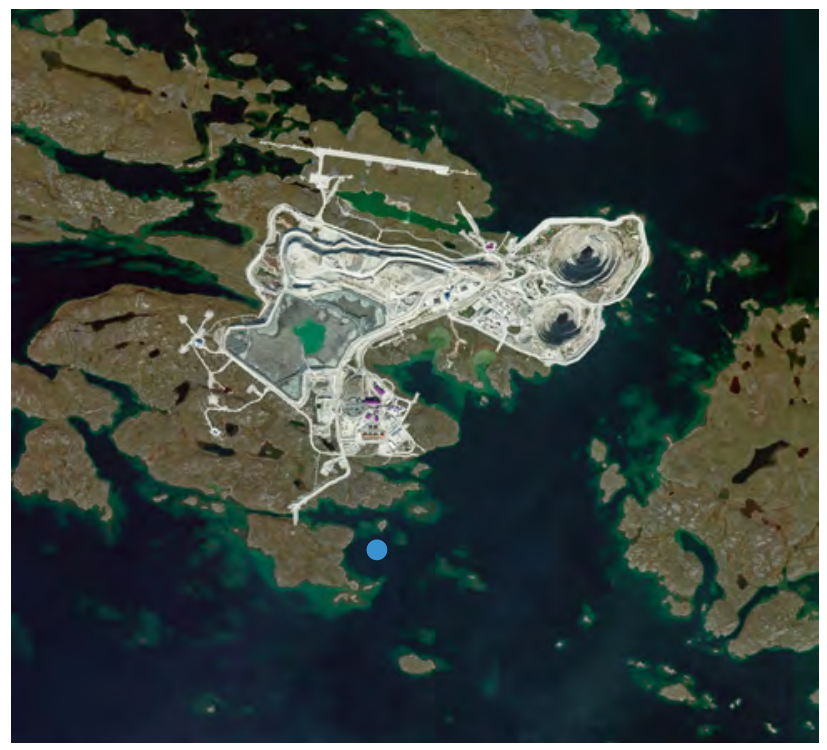

Figure 6. This photo, taken from space in August 2014, shows the A154 (top) and A418 (bottom) open pits on the right side of the image. Since the kimberlite pipes were initially covered by Lac de Gras, it was necessary to first construct dikes around the pipes to prevent water from flooding the open pits and underground mine workings. The A21 kimberlite pipe is also under the lake-its location is indicated by the blue dot. Photo courtesy of Diavik Diamond Mine.

The retention dikes around the kimberlite pipes prevent water from flowing from Lac de Gras back into the open pits and the underground workings. Figure 7 shows that the dike is constructed with a flexible concrete water barrier that is anchored to the pressure-grouted bedrock. This wall is supported on both sides by a large volume of crushed granite waste

Figure 7. This cross-section illustrates the design of the water retention dikes that were built around the kimberlite pipes to allow open-pit and underground mining operations. Construction of the dike beneath the lake and across small islands presented engineering challenges. Diagram courtesy of Diavik Diamond Mine.

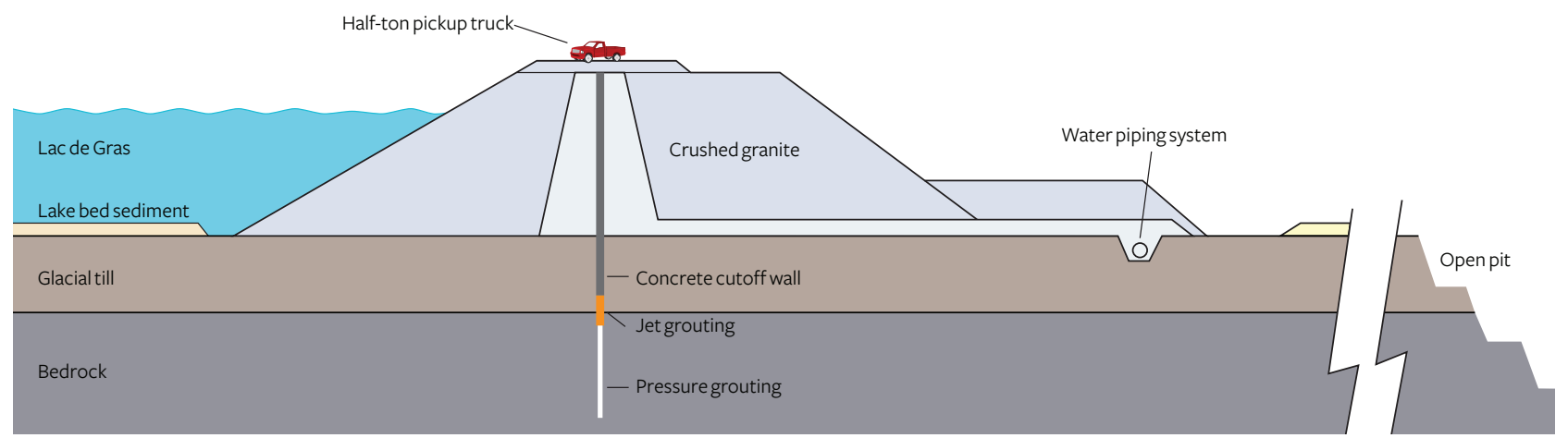




\section{Box C: The ArCtic ICE RoAD}

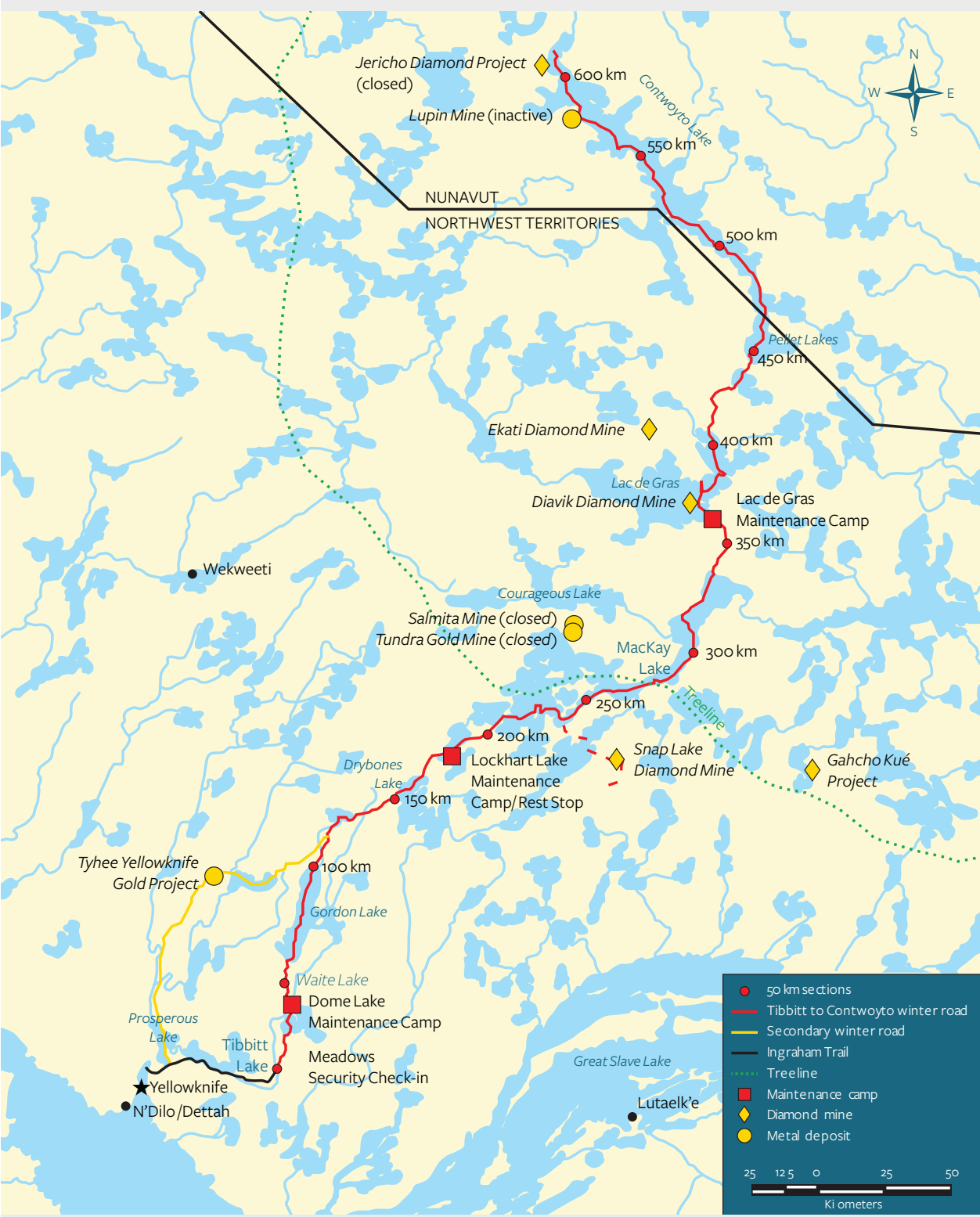

Figure C-1. This map, taken from Braden (2011), shows the arctic ice road that extends north from Yellowknife.

Based on initial assessments of diamond deposits in the Canadian north, it was evident that the kimberlite pipes could only be exploited by large-scale operations. This meant moving building materials, machinery, heavy equipment, and supplies over long distances to the mining sites over a period of many years. The terrain in this very remote region is impassable by large vehicles for much of the year, and flying is often the only way to transport people and supplies. Yet this mode of transportation was impractical and uneconomical, given the volume and heavy weight of material needed at the mine sites.

Most of the tundra in this region is permanently frozen, but during the brief summer months the permafrost thaws slightly. Because the underlying ground is frozen, water cannot sink any lower and so it forms 
shallow lakes and marshes. Due to the marshy tundra and numerous lakes, movement of large equipment and supplies by truck depends on the creation of an ice road that operates for only eight weeks during the winter months. With the arrival of very cold temperatures in November, the lakes and marshes become completely solid. By February, the ice on the lakes thickens to more than a meter and becomes capable of supporting heavy trucks.

In 1982, a winter road to service the mining areas was constructed from just north of Yellowknife to Contwoyto Lake, a distance of approximately $600 \mathrm{~km}$ (figure C-1). This is the longest heavy-haul ice road in the world, and $85 \%$ of it runs over frozen lakes. The road must be rebuilt every year between November and January. Using snowplows, crews work through 20-hour nights, enduring wind chills that can reach $-70^{\circ} \mathrm{F}$, to create a 50meter-wide path. Over the frozen lakes, the road consists of two lanes in each direction, but there is only one lane in each direction over land (figure C-2). The road is open for about eight weeks a year, so planning and scheduling of traffic is critical to sustain the diamond mines for the coming year. Using the road, the Diavik mine is approximately $425 \mathrm{~km}$ from Yellowknife.

The winter road is privately owned and maintained by a consortium of major mining companies. Use of this shared lifeline requires special safety training and licensing for all truck drivers. Three maintenance camps are located along the route. Loaded trucks must maintain a 500-meter separation and limit their speed to 15 to 20 miles per hour to prevent damage to the roadbed. A maintenance crew travels the route each day to check ice thickness, using ground-penetrating radar to ensure the trucks can be supported. A dispatch office controls the flow of truck traffic, and the consortium maintains a small security force that monitors operations. With warmer temperatures melting the ice in April, the road can no longer be used. Any heavy equipment, spare parts, construction materials, fuel, explosives, or bulk supplies needed at Diavik and other mines throughout the year must be brought in before then. Of special concern to the indigenous communities along the route are fuel spills that would damage the environment.

In 2014, the ice road operated for a period of 60 days during February and March, with a daily average of 118 truckloads carrying about 35 tonnes per load. A total of 7,069 northbound loads carried 243,928 tonnes of supplies. Braden (2011) provides many interesting stories and insights about the history, construction, and operation of this important economic lifeline for the arctic region of Canada.
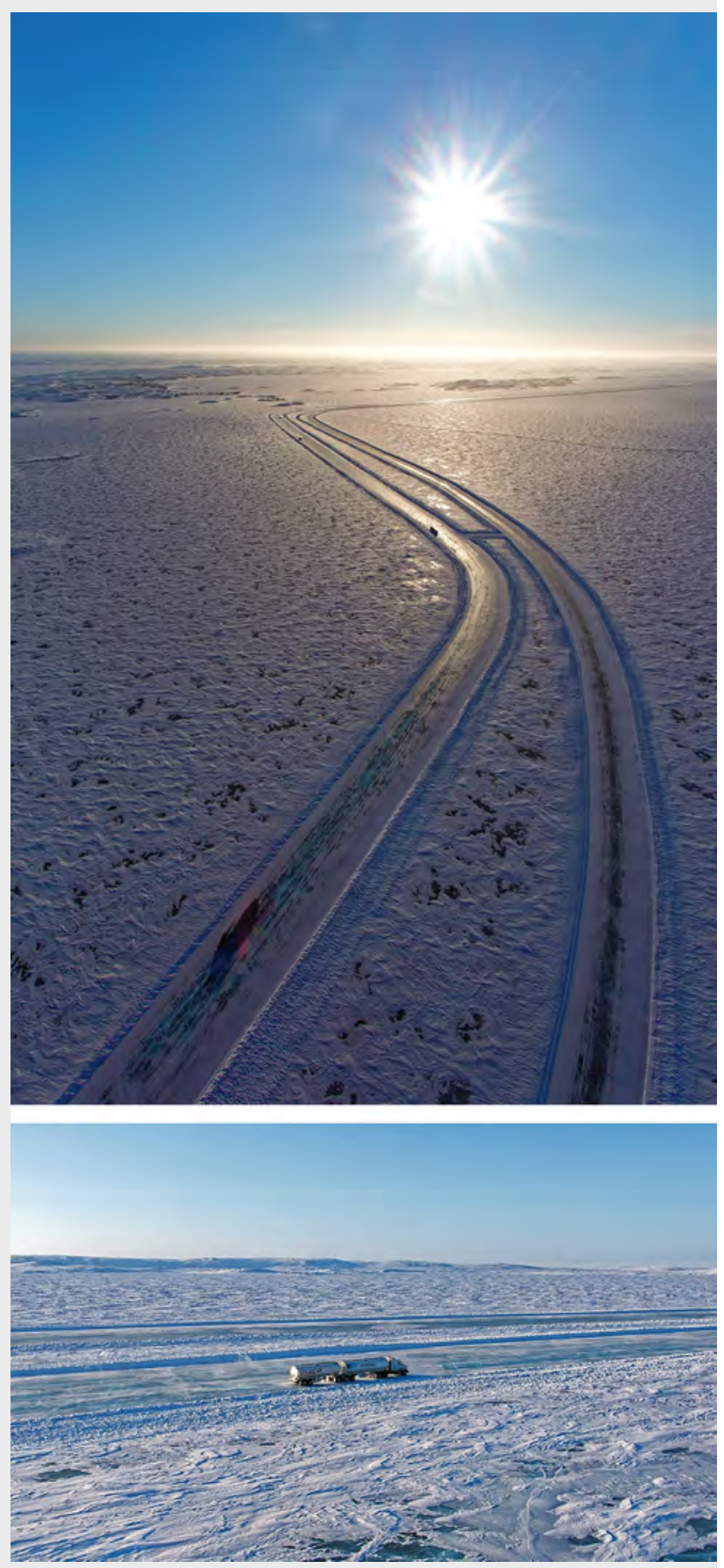

Figure C-2. These photos show a section of the arctic ice road, by which fuel, equipment, and supplies are brought by large trucks to the Diavik and other mines in northern Canada. Photos courtesy of Diavik Diamond Mine. 


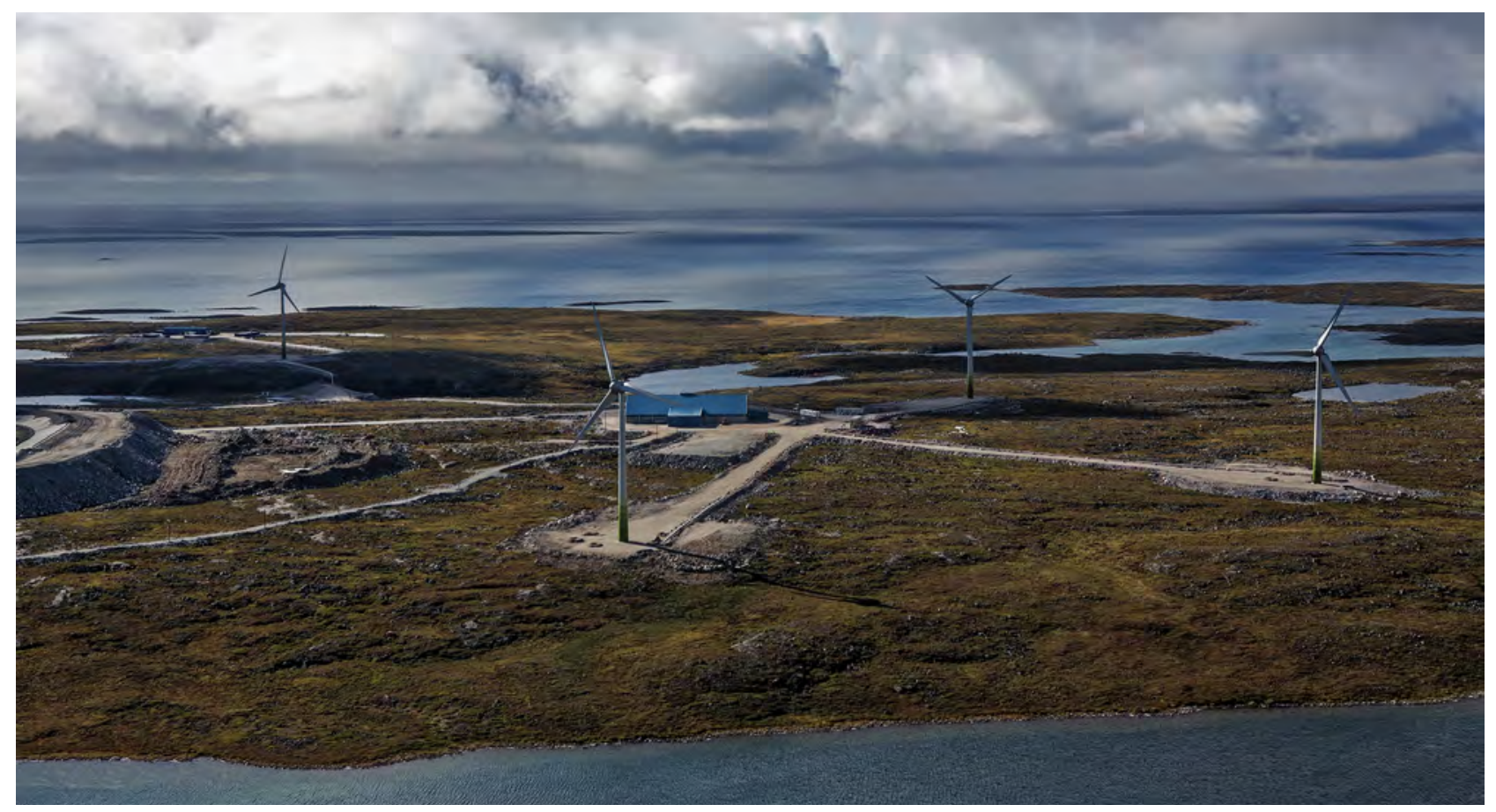

Figure 8. The wind farm, with its four large turbines, produces a significant amount of electrical power for the Diavik mine. After the rest of the facility is dismantled and removed with the end of mining, expected in 2024 , the wind farm may be donated to a local community to provide electrical power. Photo courtesy of Diavik Diamond Mine.

rock. Several hundred sensors continually monitor temperature, pressure, and ground movement to ensure the structural integrity of the dikes. The ground that acted as the dike foundation was permanently frozen beneath the land surface but not beneath the lake, so special equipment was needed to maintain the permafrost in those locations. Where the dike crosses an island, special refrigeration systems known as "thermosyphons" were installed to remove heat and allow the permafrost below the lake to remain frozen.

The two initial crushed-rock dikes (surrounding the A154 and A418 pipes) total more than five kilometers in length. They stand as high as 32 meters above the lake bed and are wide enough to allow two large vehicles to pass one another. The dikes were constructed using 4.5 million tonnes of granite waste rock.

Because it is so remote, the mine must operate as a self-contained community. The site covers 10.5 square kilometers and contains a dormitory complex, a dining area, recreational and education facilities, an office and maintenance building, a warehouse, and an enclosed maintenance facility where even the largest hauling trucks used at the mine can be worked on year-round. Emergency response and medical services are also available. A 1,600-meter airstrip on the site can accommodate large transport aircraft throughout the year. All principal mine buildings are heated by a boiler plant and connected by elevated, well-lit enclosed corridors so that workers can pass from building to building without being exposed to the harsh winter climate.

Minimal amounts of water are taken from Lac de Gras. A system has been constructed around the island to collect water for reuse or for cleaning in a treatment plant before it is returned to the lake. A separate plant treats all domestic sewage.

A diesel power plant generates electricity for the entire site. A year's supply of diesel fuel is stored onsite for the power plant as well as the mining vehicles. Excess heat from the power plant is used to warm some of the buildings and to heat water used in processing the kimberlite ore. In September 2012, a wind farm (figure 8) was added to provide a renewable source of electrical energy via a wind-diesel hybrid power plant. The wind farm, the first of its kind in the Canadian subarctic, lowered carbon emissions from the mining operations and reduced the need for diesel fuel to be hauled in.

A separate plant produces crushed granitic rock for dike construction, maintenance of the airport runway 
and road surfaces, and for use underground to backfill the open tunnels and other workings once the kimberlite ore is removed. Explosives used in mining operations are stored in a secure facility on-site.

\section{MINING AND PRODUCTION}

Operations. Open-pit operations on the two ore bodies of the A154 pipe began in January 2003, and mining of the A418 pipe followed in 2007 (figure 9). This type of mining was economically viable because the tops of the kimberlite pipes were within 20 meters of the surface, minimizing the amount of waste rock that had to be stripped away to expose them (figures 10 and 11). Kimberlite ore and granite rock overburden from the pits are hauled away by vehicles, without a system of ore buckets or conveyor belts. As surface mining is

Figure 9. Aerial view of the A154 and A418 open pits (top and bottom, respectively). Photo courtesy of Diavik Diamond Mine.
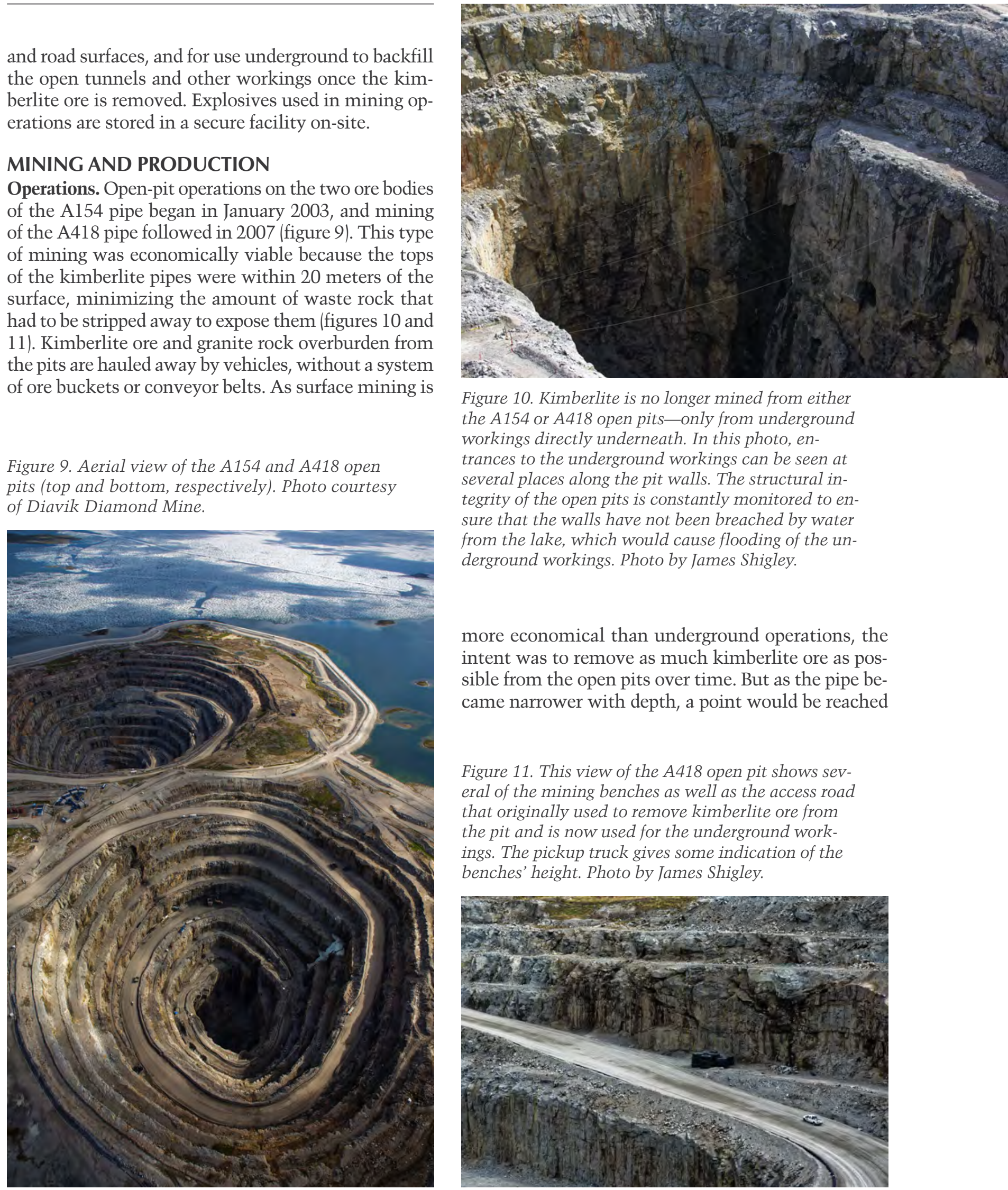

Figure 10. Kimberlite is no longer mined from either the A154 or A418 open pits-only from underground workings directly underneath. In this photo, entrances to the underground workings can be seen at several places along the pit walls. The structural integrity of the open pits is constantly monitored to ensure that the walls have not been breached by water from the lake, which would cause flooding of the underground workings. Photo by James Shigley.

more economical than underground operations, the intent was to remove as much kimberlite ore as possible from the open pits over time. But as the pipe became narrower with depth, a point would be reached

Figure 11. This view of the A418 open pit shows several of the mining benches as well as the access road that originally used to remove kimberlite ore from the pit and is now used for the underground workings. The pickup truck gives some indication of the benches' height. Photo by James Shigley.

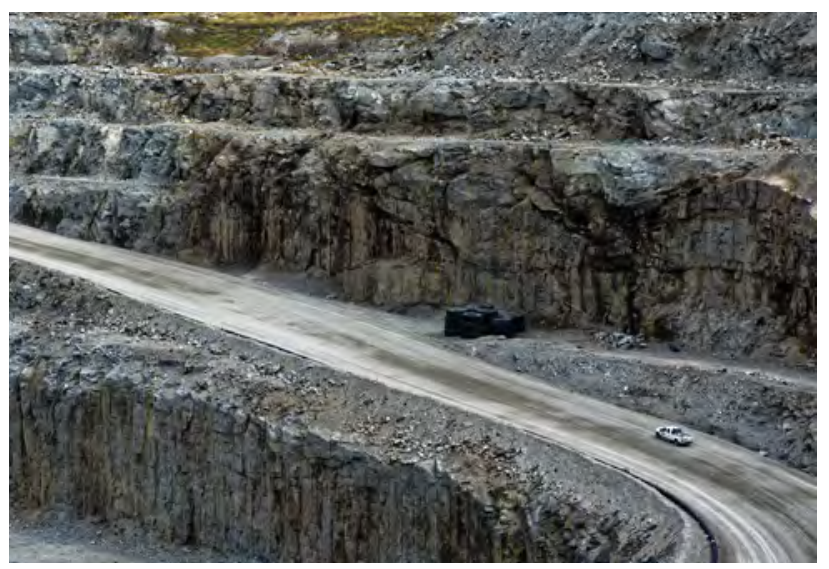




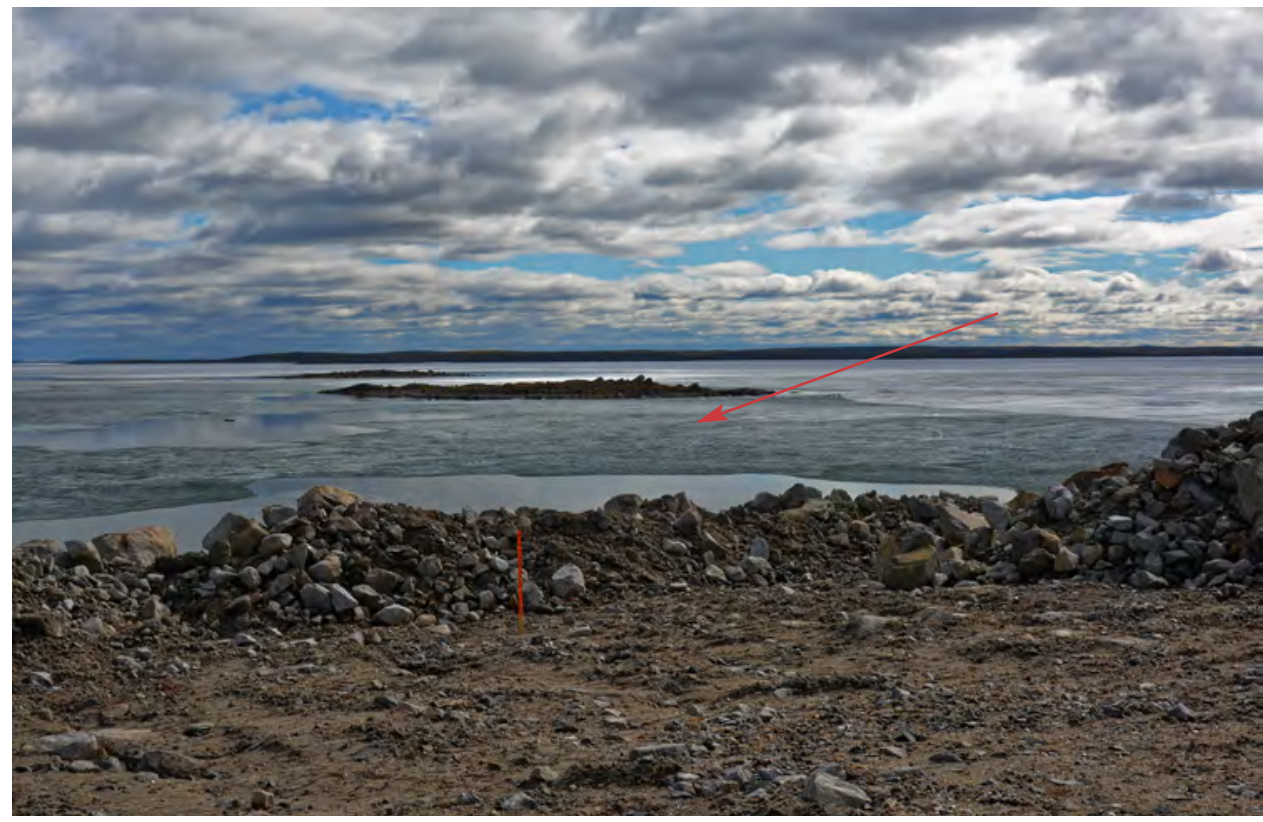

Figure 12. The A21 kimberlite pipe lies beneath the still-frozen waters of Lac de Gras. Its location is indicated by the red arrow. The future water retention dike will extend from the land at both edges of the photo to the nearer of the two islands. Once the dike is constructed, open-pit mining of the pipe can begin. Photo by James Shigley.

where ore could no longer be removed by vehicle haulage, and surface mining would then cease. In 2012 , after three years and a cost of CAD $\$ 800$ million, Diavik completed the transition to underground operations for the three pipes being exploited.

In the fall of 2014, Rio Tinto announced plans to develop the fourth kimberlite pipe on the property. Construction of the dike surrounding the A21 pipe will take four years; it will extend $2.2 \mathrm{~km}$ and require 3 million tonnes of crushed granite (figure 12). Production from the A21 pit is scheduled to begin in late 2018. Output from this pipe will not appreciably extend the life of the mine. Rather, it will offset the approaching decline in production from the underground operations and allow a continuation of existing kimberlite ore levels through the processing plant for several years.

Diavik's original plan called for the eventual development of underground mining operations, primarily by ore trucks driving down a tunnel from the surface (figure 13). Prior to tunneling, an extensive geotechnical survey of the hydrogeology of the ore bodies and surrounding host rocks was carried out. The design of the open pits and the choice of surface mining methods took into account that the pits would be directly above the underground workings. To date, some $20 \mathrm{~km}$ of interconnected underground tunnels have been constructed. These heated and ventilated

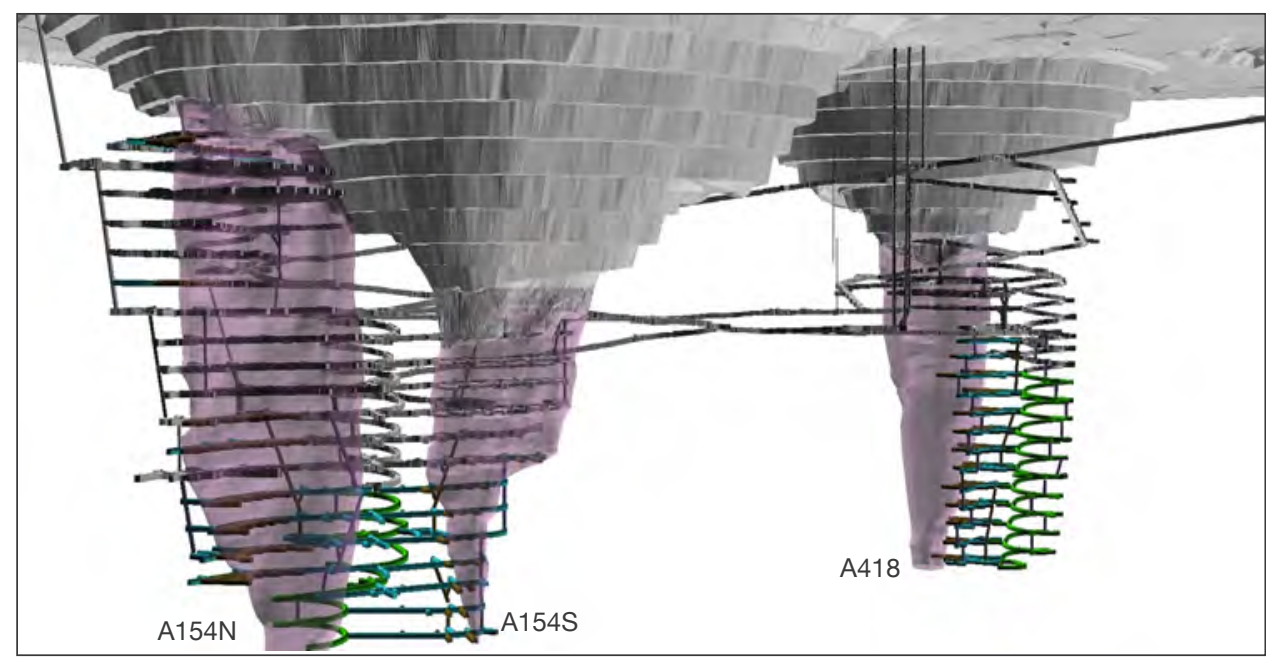

Figure 13. A computergenerated plan of the underground workings that lie below the two open pits of A154 (left) and A418 (right). The workings shown in black are existing tunnels, whereas those in blue-green represent future tunnels that have not yet been installed to reach lower portions of the kimberlite pipes. The long straight tunnel that slopes upward to the right side of the image is the access tunnel. Image courtesy of Diavik Diamond Mine. 


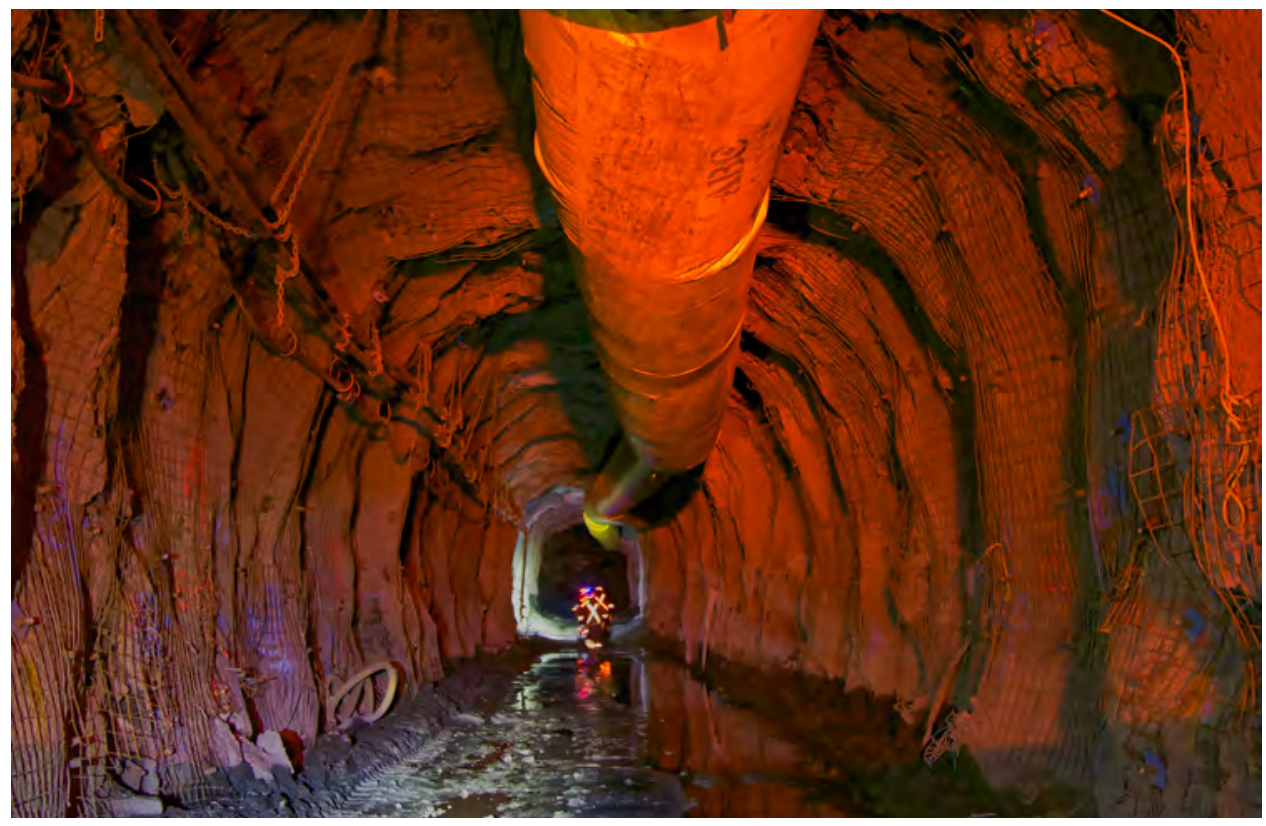

Figure 14. View of one of the underground tunnels that extend across the entire diameter of a kimberlite pipe. The tunnel's width and height must accommodate a mining vehicle. Photo by James Shigley.

tunnels include rescue bays where miners can retreat for safety in emergencies, vehicle repair shops, ore passes, ventilation systems, water pumping stations, and storage areas (figures 14 and 15). The underground tunnels were designed to prevent rock in the overlying open pits from subsiding. Although surface mining of A154 and A418 has finished, the pits are the secondary access to the current underground workings via two entrance portals. Continuous monitoring of the now-unused open pits ensures the structural integrity of the pit walls, preventing breaching of the dikes from the surrounding lake and flooding of the underground workings.

Two types of underground mining were selected based on safety, cost, and other considerations. A technique known as blast-hole stoping (BHS) was chosen for A154N because of the stronger, more competent kimberlite rock in this pipe. It is a bottom-up bulkmining method in which several days of ore production can be created with a single explosion. Holes are drilled vertically from a higher stope (mining cavity) and filled with explosives. When blasted, the broken ore falls to a lower stope, where it can be removed by a scoop loader and ore hauler. Once all the broken ore is removed, the open lower stope is completely backfilled with cemented waste rock, and the process is repeated at the higher stope.

A top-down bulk-mining method known as sublevel retreat (SLR) is used in the A418 and A154S pipes, where the kimberlite ore is weaker but contained within a more competent granite host rock. In this method, a series of horizontal tunnels on a single level is excavated into the pipe, and sections of ore above the tunnels are broken up using explosives. The broken ore falls into the tunnel and is removed. Once all the ore on the level is removed, a new set of tunnels is created farther down in the pipe, and the excavation process is repeated. The process creates a large open space within the pipe.

All three pipes are being excavated concurrently, and a mixture of both "hard" and "soft" kimberlite ore is sent through the processing and recovery

Figure 15. When a tunnel is excavated, this machine is used to install a metal safety screen to prevent debris from falling from the walls or ceiling. Photo courtesy of Diavik Diamond Mine.

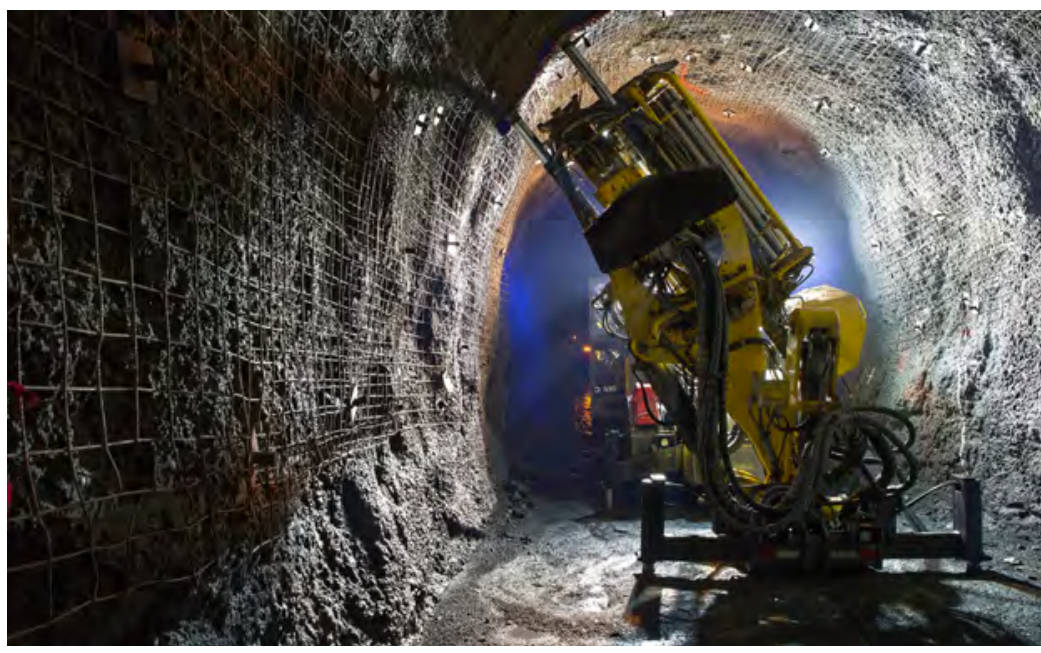




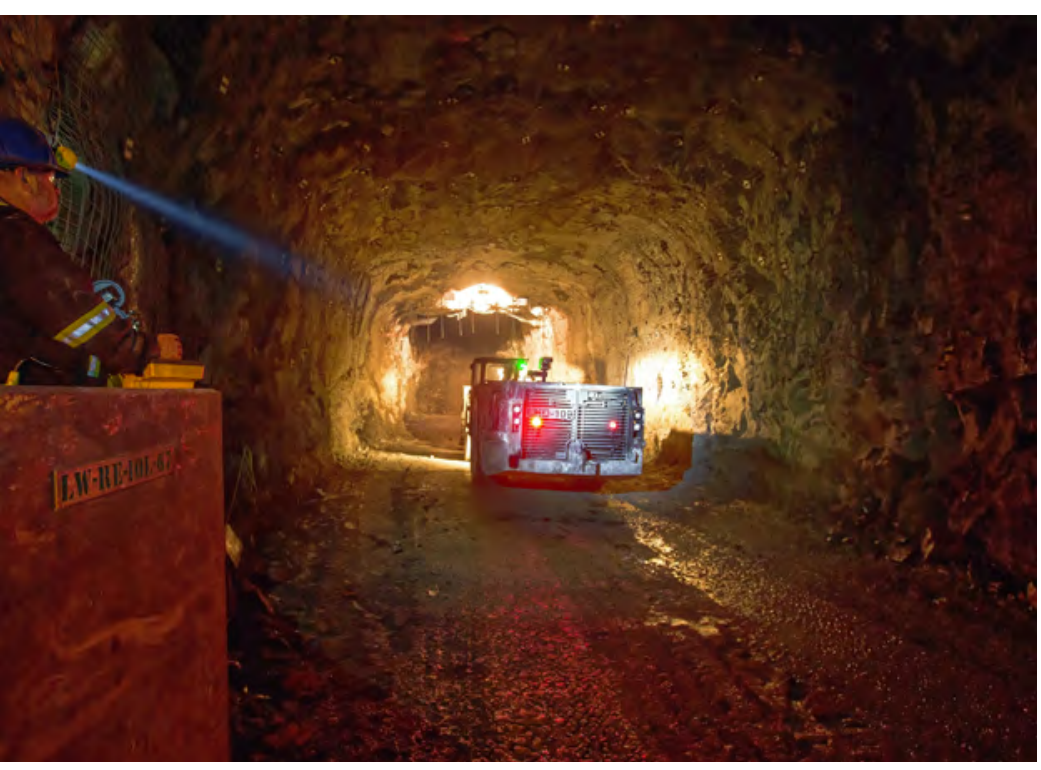

Figure 16. A long straight haulage tunnel is used to access the underground workings and haul kimberlite ore from the workings to the surface. Photo courtesy of Diavik Diamond Mine.

plants. Although the mine was originally designed to handle 1.5 million tonnes of ore, this capacity was expanded to 2 million tonnes through operational improvements without the need for additional capital investment (Diavik diamond mine: 2014 sustainable development report, 2015). Kimberlite ore and waste rock are brought from the underground workings to the surface by haulage trucks using three portal entrances, and the material is dumped in a designated location on-site. Larger trucks haul the ore to the processing plant, and any waste rock goes to a separate dump location (figures 16 and 17). The decision to use trucks to haul ore and waste rock from underground, as opposed to a conveyor belt or ore bucket system, was based in part on the fact that the loaders and trucks from the open-pit mining operations were already available.

The kimberlite ore is processed in a large building on-site (figure 18) that is estimated to be 11 stories high and approximately 150 meters long and 40 meters wide. The ore first passes through a series of powerful magnets, which remove the unwanted pieces of steel mesh that are used to stabilize the tunnel walls. The ore is then crushed to progressively smaller pieces, removing the finer material. Diamonds are separated from the crushed ore by nonchemical, density-based methods to create a diamond-rich heavy-mineral concentrate (figure 19). Next, X-ray sorting uses fluorescence to recover diamonds from the concentrate. The processed ore material is then stored in a designated area on-site.

Although the diamond grade in the Diavik kimberlite pipes is very high compared to other primary mines, diamonds are still in very low concentrations overall, so a large amount of kimberlite ore must be

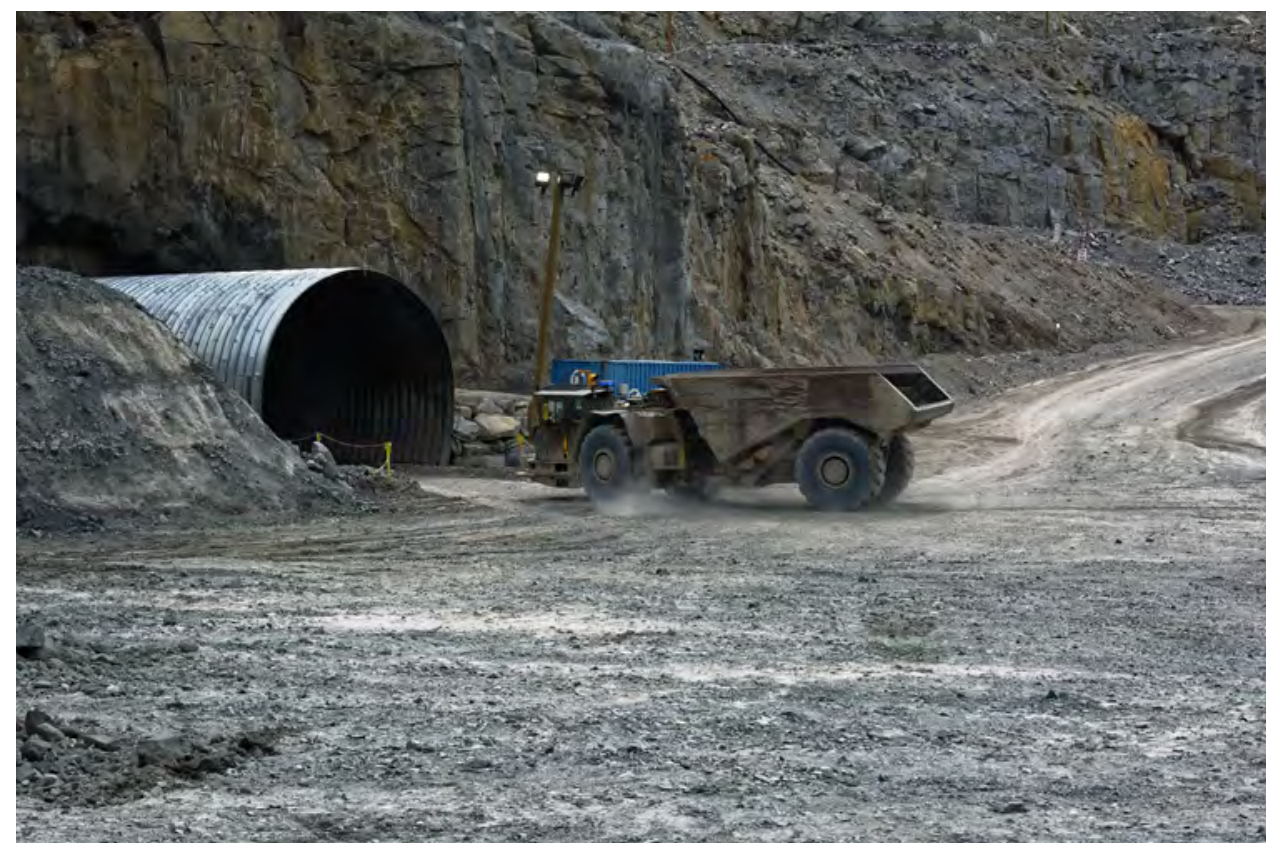

Figure 17. An ore hauler enters the access tunnel to reach the underground workings. Photo by James Shigley. 


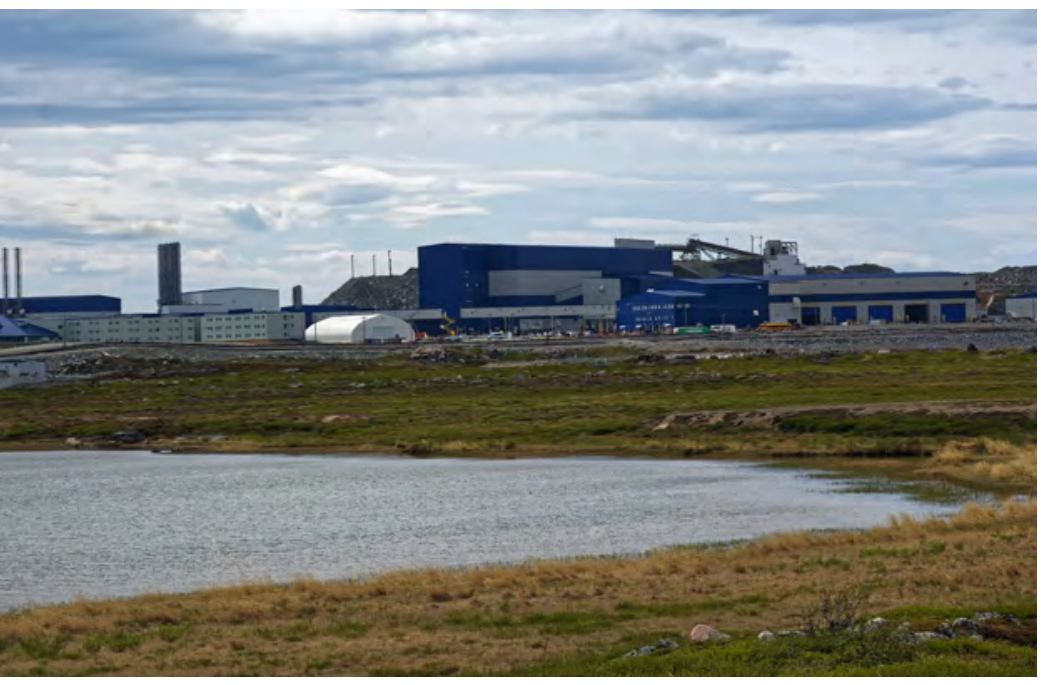

Figure 18. This view shows the ore processing plant (center), equipment repair shop (right), and office/dormitory complex (left). Photo by James Shigley.

extracted and processed to recover them. As at other major mines, it is always surprising to hear that most workers have "never seen a diamond in the mine." Processing of the mixed kimberlite ore brought up

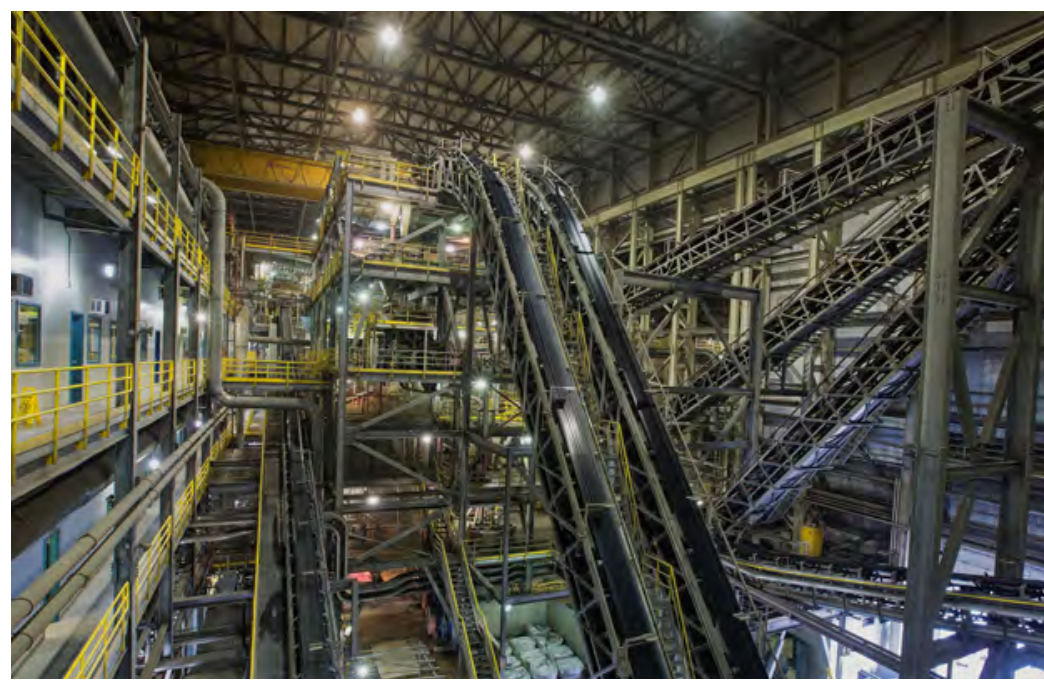

Figure 19. The interior of the ore processing plant, where each step of the processing sequence to liberate the diamonds from the kimberlite ore takes place. Photo courtesy of Diavik Diamond Mine.

from the workings of the A154 and A418 pipes involves a complex series of steps to create progressively smaller sizes to liberate the diamonds from the host rock (figures 20 and 21).

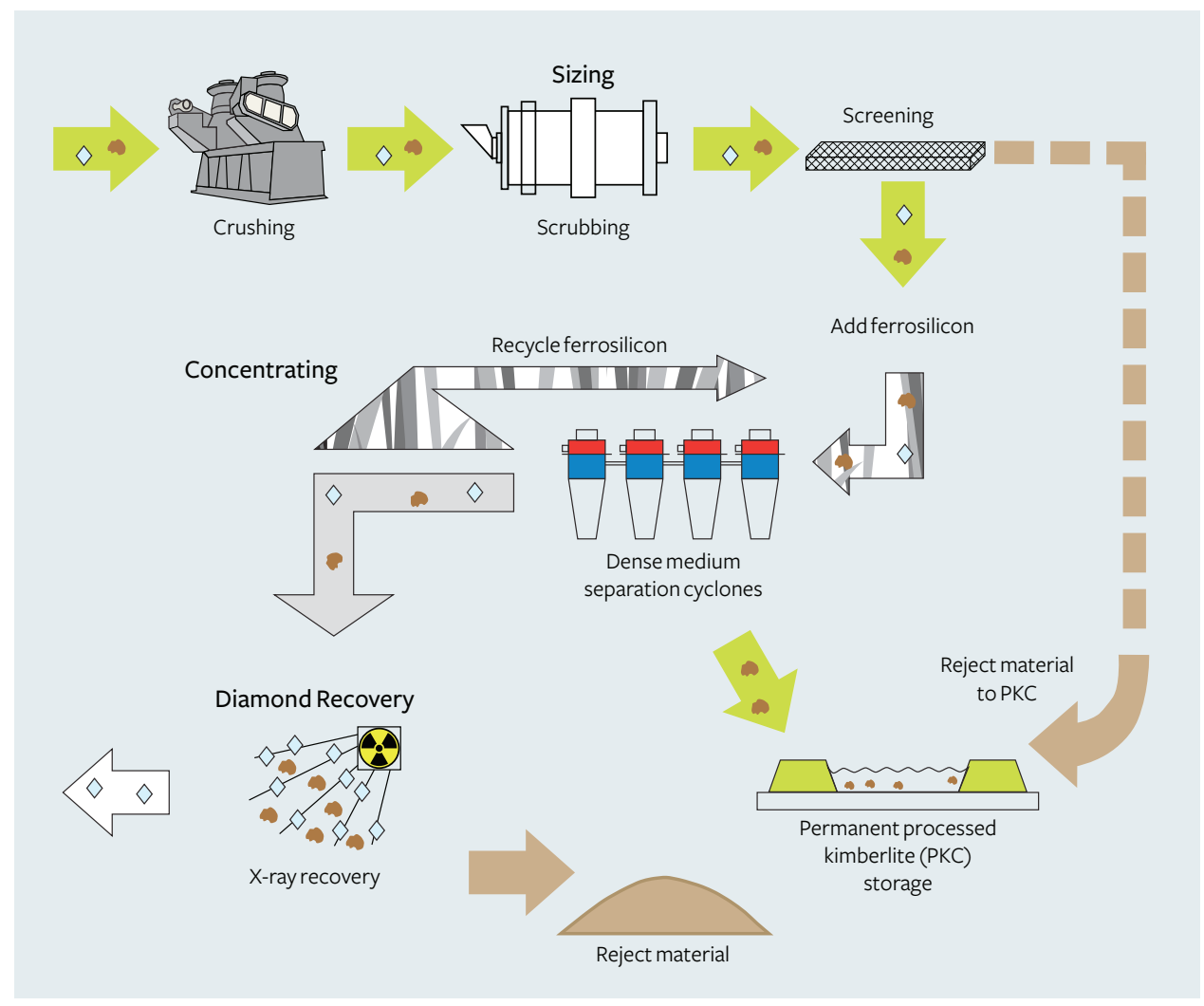

Figure 20. This diagram illustrates the steps in processing the bulk kimberlite ore to recover the diamonds. Courtesy of Diavik Diamond Mine. 


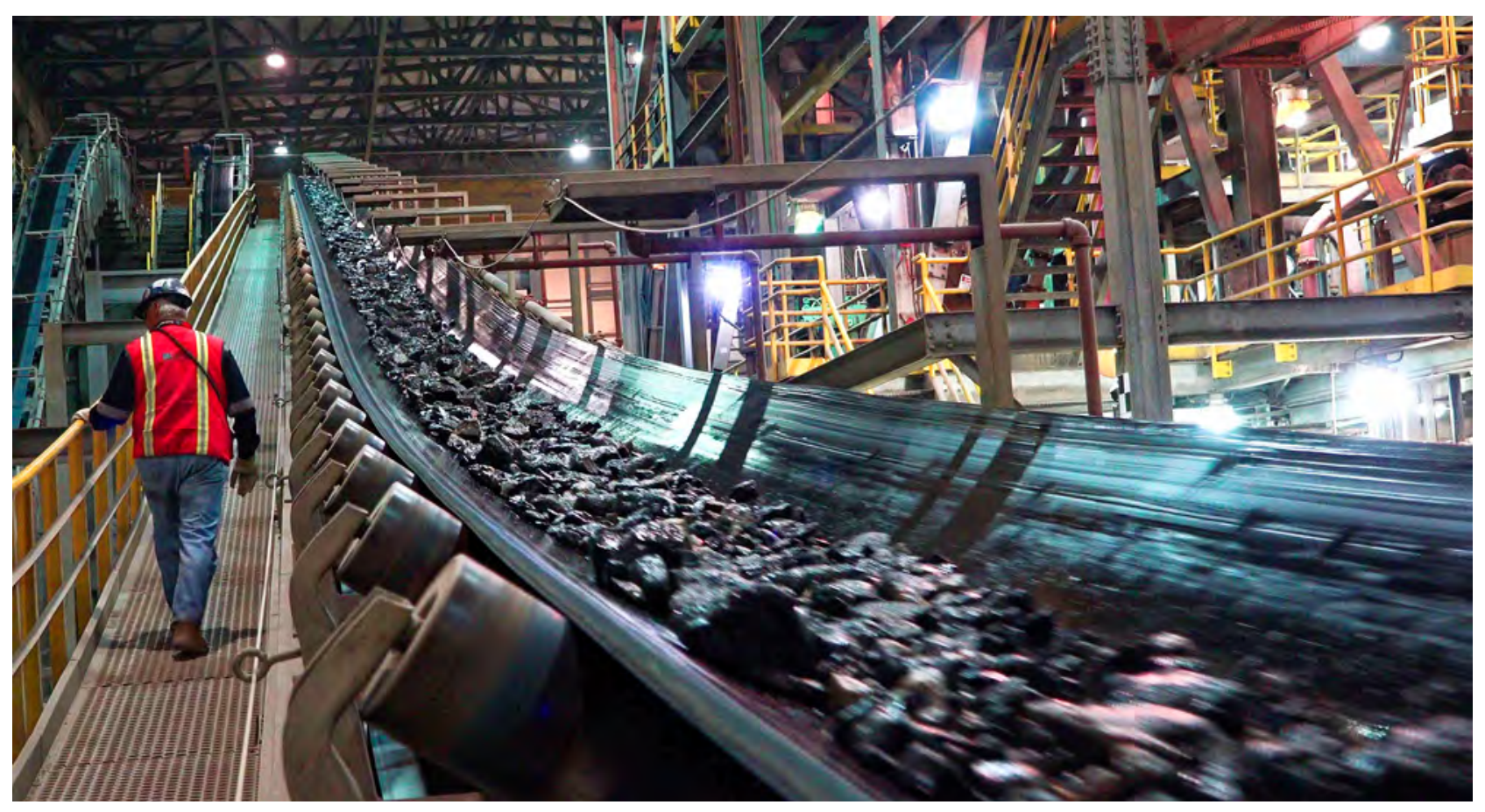

Figure 21. The kimberlite ore is transported by conveyor belts between different stages of the processing sequence. Photo by James Shigley.

Grease tables are used to retrieve diamonds that cannot be efficiently recovered by X-ray fluorescence technology. Recovery of all diamonds takes place in a restricted area of the plant. Under stringent security, all diamonds are weighed, sorted, and documented before being packaged and flown to Yellowknife. At the product splitting facility, the rough diamonds are cleaned, sorted, and valued for government royalty purposes. The diamonds are separated by size for distribution to the two joint-venture partners, according to the production agreement. Once separated, the diamonds follow different paths for manufacturing and marketing.

Personnel. At the end of 2015, Diavik had approximately 1,000 employees, of whom $55 \%$ were from the Northwest Territories and $25 \%$ from the indigenous communities. Most employees work on a rotation, with two weeks of 12 -hour shifts at the mine, followed by two weeks at home. Managerial staff work four days at the mine followed by three days off-site. Employee transportation to and from Yellowknife is provided by company or chartered aircraft. The mine operates around the clock every day of the year.
Safety. An extensive safety management system governs all aspects of mine operations. The system begins with training of all employees, safety standards for every area of activity, and regular reviews to continually monitor and improve safety practices. Before beginning any work activity, employees conduct a quick

Figure 22. Mine safety is paramount in the harsh winter climate of Diavik. Photo courtesy of Diavik Diamond Mine.

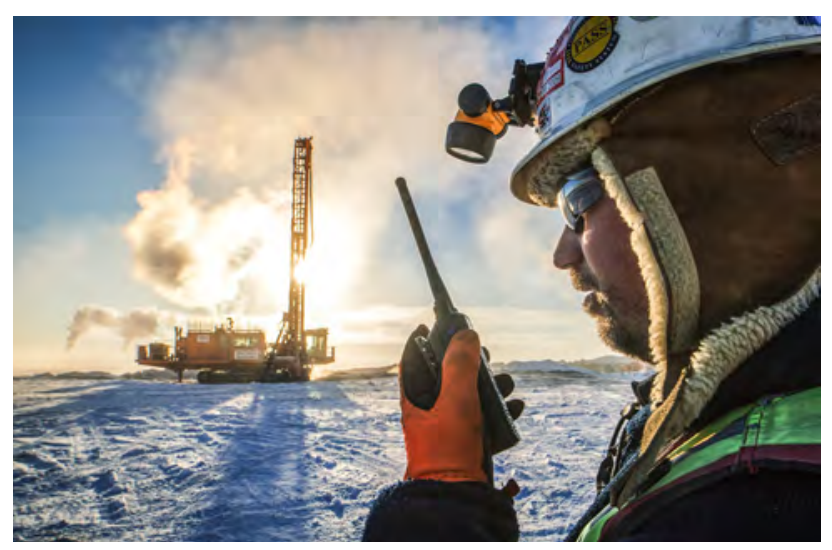


TABLE 1. Proven and probable kimberlite ore reserves at the Diavik mine, as of December 2015.

\begin{tabular}{lccc}
\hline Pipe & $\begin{array}{c}\text { Tonnes } \\
\text { (millions) }\end{array}$ & Carats/tonne & $\begin{array}{c}\text { Carats } \\
\text { (millions) }\end{array}$ \\
\hline A154N & 8.8 & 2.4 & 20.8 \\
A154S (underground) & 1.5 & 3.3 & 5.1 \\
A418 (underground) & 4.6 & 3.6 & 16.7 \\
A21 (future open pit) & 3.7 & 2.7 & 10.0 \\
Ore stockpile & 0.1 & 3.5 & 0.3 \\
Totals & $\mathbf{1 8 . 7}$ & $\mathbf{2 . 8}$ & $\mathbf{5 2 . 8}$ \\
\hline
\end{tabular}

Adapted from Diavik diamond mine: 2015 sustainable

development report (2016).

Tables may not add up due to rounding.

safety check to identify and discuss potential hazards associated with the activity, as well as preventive measures that can be taken. The entire mine site is inspected regularly by outside agencies to ensure that all operations are conducted in a manner that protects and enhances worker safety and the environment.

Mine safety is particularly critical when operating in a harsh environment (figure 22). In winter, mining activities can be disrupted by whiteout conditions, where the lack of visibility causes spatial disorientation and can be life-threatening. These conditions occur about four times per year and typically last 8 to 12 hours. Weather monitoring is conducted to warn mine staff of whiteout conditions, as well as the onset of very low temperatures.

Production. With the exception of 2009, when demand was low due to the global financial crisis, annual production of rough diamonds at Diavik has consistently surpassed six million carats. As shown in table 1, Diavik's total mineral reserves at the end of 2015 were 18.7 million tonnes of unmined kimberlite ore containing an average of 2.8 carats of diamonds per tonne, for a total of 52.8 million carats of diamonds as proven or probable reserves. Table 2 presents annual production data from 2003 to 2014.

While the Diavik mine is not known for large diamonds, its kimberlite pipes contain exceptionally high grades (3-5 carats/tonne) of moderate- to high-value diamonds (compared to 0.5 to 1 carats/tonne in other locations). Production from the two operating pipes is valued well above the Kimberley Process average of US $\$ 116$ per carat $-\$ 135$ per carat for A 154 S and $\$ 175$ per carat for $\mathrm{A} 154 \mathrm{~N}$. The average value for $\mathrm{A} 418$ is $\$ 95$ per carat (Dominion Diamonds, 2015).

Diamond crystals from the mine exhibit common forms such as octahedra, dodecahedra, macles, cubes, and aggregate shapes. Colorless crystals predominate, though brown and rarely yellow diamonds also occur; some others have a gray surface coating (Carlson et al., 1999).

\section{CORPORATE SOCIAL RESPONSIBILITY}

Relationship with Indigenous Communities. The 1991 diamond rush transformed the economy and society of the Northwest Territories. The subsequent development of several major diamond mines in this remote region transpired against the backdrop of a new relationship between the mine owners, the national government, and local communities. Over the past four decades, legislation, land claims, and legal challenges have strengthened the rights of Canada's indigenous communities over the land and water resources within their traditional territory. An important component of this power-sharing and cross-cultural governance over important land-use, environment, and wildlife decisions has been the increasing reliance on management boards with representation from the federal government, the mining companies, and local communities.

The company maintains a socioeconomic monitoring agreement with the territorial government, as well as environmental protection agreements with the indigenous communities and the federal and territorial governments. Councils involving the indigenous peoples have been consulted on a regular basis about mining operations since the discovery of the diamond occurrence in 1993. Discussions with these local groups have prompted revisions to the mine operation and closure plans, and this is expected to continue as long as the mine is in operation.

A representative body called the Traditional Knowledge Panel advises the company based on centuries of local habitation. For example, traditional understanding of wildlife habitats is being incorporated into the reclamation plan for revegetating the area. There was some discussion in this panel of how far to go in the revegetation process. While some people from the community believed that nature would "heal itself," most panel members understood that environmental disruptions from mine operations were more extensive than naturally occurring events, and that a more aggressive reclamation process was necessary (Diavik diamond mine reclamation review, 2007; Diavik diamond mine: 2014 sustainable development report, 2015).

As the mine was being developed, agreements were put into place to ensure that benefits would be 
TABLE 2. Annual production of kimberlite ore and recovered diamonds from the Diavik mine, 2003-2014.

\begin{tabular}{|c|c|c|c|c|c|c|c|c|c|}
\hline & & Open pit & & & Underground & & & Total & \\
\hline Year & $\begin{array}{l}\text { Millions of } \\
\text { tonnes }\end{array}$ & $\begin{array}{l}\text { Millions of } \\
\text { cts. }\end{array}$ & $\begin{array}{l}\text { Cts. per } \\
\text { tonne }\end{array}$ & $\begin{array}{c}\text { Millions of } \\
\text { tonnes }\end{array}$ & $\begin{array}{l}\text { Millions of } \\
\text { cts. }\end{array}$ & $\begin{array}{l}\text { Cts. per } \\
\text { tonne }\end{array}$ & $\begin{array}{l}\text { Millions of } \\
\text { tonnes }\end{array}$ & $\begin{array}{l}\text { Millions of } \\
\text { cts. }\end{array}$ & $\begin{array}{c}\text { Cts. per } \\
\text { tonne }\end{array}$ \\
\hline 2003 & 1.193 & 3.833 & 3.2 & - & - & - & 1.193 & 3.833 & 3.2 \\
\hline 2004 & 1.950 & 7.575 & 3.9 & - & - & - & 1.950 & 7.575 & 3.9 \\
\hline 2005 & 2.222 & 8.271 & 3.7 & - & - & - & 2.222 & 8.271 & 3.7 \\
\hline 2006 & 2.331 & 9.829 & 4.2 & - & - & - & 2.331 & 9.829 & 4.2 \\
\hline 2007 & 2.400 & 11.943 & 5.0 & - & - & - & 2.400 & 11.943 & 5.0 \\
\hline 2008 & 2.414 & 9.225 & 3.8 & - & - & - & 2.414 & 9.225 & 3.8 \\
\hline 2009 & 1.359 & 5.565 & 4.1 & - & - & - & 1.359 & 5.565 & 4.1 \\
\hline 2010 & 1.765 & 5.625 & 3.2 & 0.326 & 0.875 & 2.7 & 2.091 & 6.500 & 3.1 \\
\hline 2011 & 1.768 & 5.531 & 3.1 & 0.465 & 1.146 & 2.5 & 2.234 & 6.677 & 3.0 \\
\hline 2012 & 1.116 & 4.006 & 3.6 & 0.942 & 3.224 & 3.4 & 2.058 & 7.230 & 3.5 \\
\hline 2013 & 0.161 & 0.465 & 2.9 & 1.956 & 6.778 & 3.5 & 2.116 & 7.243 & 3.4 \\
\hline 2014 & - & - & - & 2.277 & 7.233 & 3.2 & 2.277 & 7.233 & 3.2 \\
\hline Totals & 18.68 & 71.867 & 3.8 & 5.966 & 19.256 & 3.2 & 24.646 & 91.122 & 3.7 \\
\hline
\end{tabular}

made available to local indigenous communities. These included job training, employment at the mine, and opportunities for local businesses to provide needed services.

Environmental Monitoring and Protection. At Diavik, all mine activities are designed to protect the environment, anticipate potential problems, and meet regulatory requirements. A surveillance network is in place to monitor the water quality in and around the mine. In addition, the effects of mining operations on local wildlife (including caribou, wolverine, bear, and fish) and habitats (e.g., changes in vegetation) are checked on a regular basis. Efforts are made to minimize the production of dust from roadways and the airstrip.

Mine Closure and Reclamation. From the beginning of mine construction, plans were initiated to return the site to its nearly original condition once mining operations cease in 2024. Progressive reclamation of the site has been ongoing and is expected to cost US $\$ 131$ million by 2030 , once all the works have been removed from the site. A group of indigenous community representatives was organized to provide recommendations for the closure plan. They offered suggestions for revegetation and the creation of corridors for local wildlife such as caribou to pass through the mine site after closure. An important subject has been reclamation of the open pits to restore the original shoreline of Lac de Gras. The processed waste kimberlite ore will be sealed in a special containment area. All buildings and other facilities will be dismantled and removed, with the exception of the wind farm, which may be donated to provide electrical power to the community.

The final steps of the closure plan will be very complex. The waste piles must be shaped to match the natural landscape, which is relatively flat with occasional low hills and granite outcrops. The slopes of the piles must be stabilized to prevent them from giving way and endangering people or wildlife. Finally, the results of the reclamation project must have a neutral effect on the balance of nature in the environment. For example, the restored terrain should make it neither easier nor more difficult for migrating caribou to escape while being hunted by the indigenous peoples. Revegetation must not unduly attract caribou to the area or deter them from migrating through it (Diavik diamond mine reclamation review \& cost estimate, 2007).

Even though Diavik was the second diamond mine to open near Lac de Gras, the joint venture faced considerable pressure from the local and federal governments, as well as environmentalists, to ensure the mine closure plan would return the land as closely as possible to its original state. This requirement came in response to the estimated 10,000 mining operations in the Canadian north that had closed with little or no reclamation plan, often posing physical or environmental hazards. For example, the Giant mine, a gold recovery operation near Yel- 
lowknife, closed in 1999 , leaving 237,000 tonnes of toxic arsenic trioxide stored in the abandoned underground workings. Negotiations are still ongoing to decide on an appropriate clean-up plan and who should pay the cleanup costs ("Giant headache," 2014).

\section{MARKETING OF DIAVIK DIAMONDS}

The rough diamond sorting process is highly automated. After recovery, the diamonds are conveyed into a secured section of the plant where they enter sorting units-large metal canisters containing progressively smaller sieves down to $3 \mathrm{~mm}$. At each sieve level, the diamonds are transferred into separate containers and packaged for shipment.

The Diavik mine is jointly owned by Diavik Diamond Mines Inc. (a wholly owned subsidiary of Rio Tinto plc) and Dominion Diamond Diavik Limited Partnership (a wholly owned subsidiary of Dominion Diamond Corporation). From the mine, the sorted diamonds are flown to a product splitting facility near the Yellowknife airport, where they are divided between the two owners-60\% to Rio Tinto and 40\% to Dominion Diamonds.

Rio Tinto. This Anglo-Australian mining conglomerate owns a $60 \%$ stake in the Diavik mine, which produced 6.7 million carats in fiscal year 2015. It also owns a $100 \%$ stake in Australia's Argyle diamond mine and sells that production in lots separate from Diavik. Rio Tinto markets all of its rough diamonds (figure 23) from a sales office in Antwerp, where it sold $70 \%$ of its four million carats from Diavik in 2015 at set prices to 17 "Select Diamantaires" who specialize in manufacturing and distributing Canadian rough and polished diamonds. These clients receive Diavik product via two-year supply contracts (Krawitz, 2015). Like De Beers, Rio Tinto schedules 10 sales, called "core sales," each year.

Five times per year, Rio Tinto also auctions key assortments from its production to engage with customers outside of its Select Diamantaire base. The company sells fancy-color diamonds and rough diamonds larger than 10.8 ct through two "Specials" tenders each year.

Rio Tinto, under its "Diamonds with a Story" platform, promotes Diavik's pure and clean Canadian origin and unique provenance. Downstream of the mine, Rio Tinto works in partnership with its Select Diamantaires to provide a tracking system, from the mine to the consumer, for Diavik diamonds (R. Ellison, pers. comm., 2016).

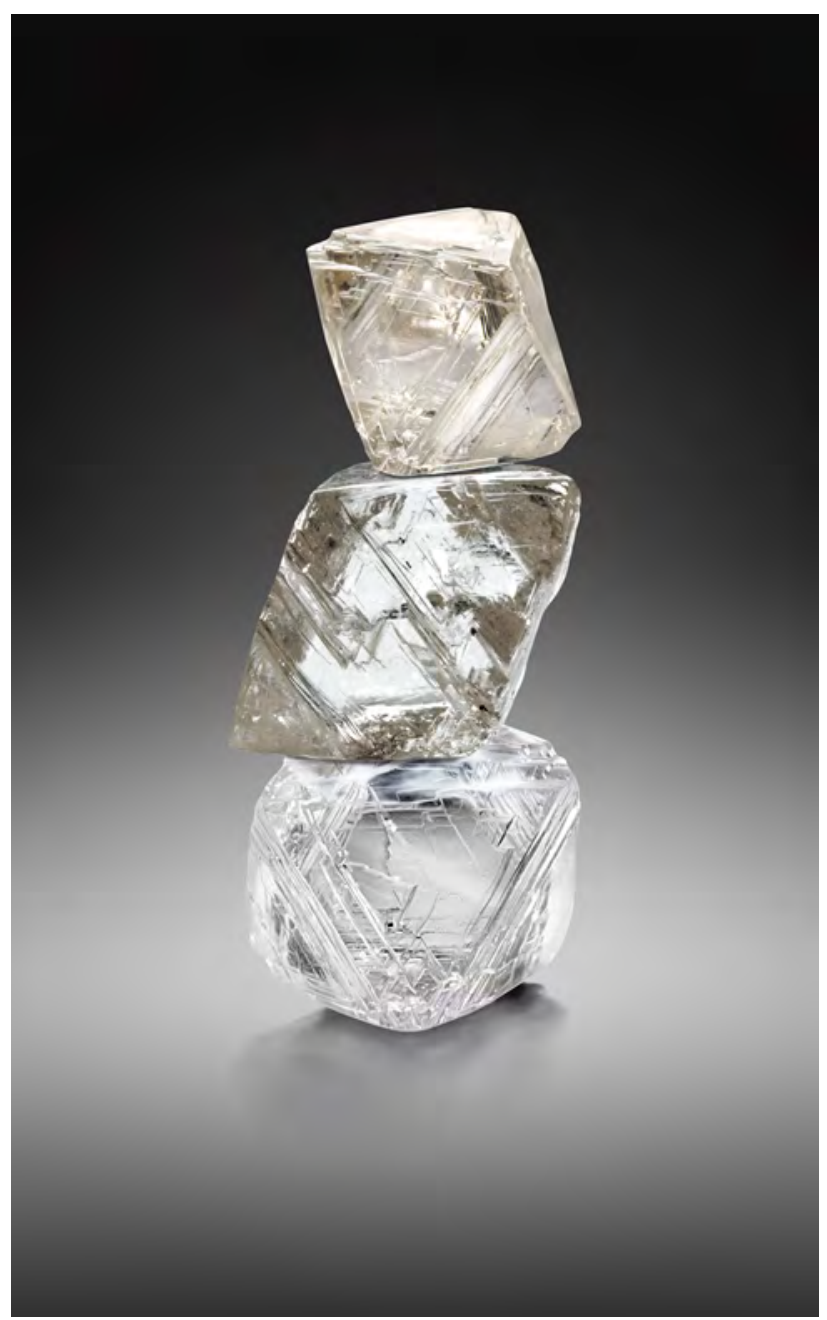

Figure 23. Rio Tinto markets its Diavik rough diamonds from a sales office in Antwerp. Photo courtesy of Rio Tinto Diamonds.

Dominion Diamond Corporation. Dominion Diamonds was originally the Canadian diamond exploration company Aber Resources, which discovered the Diavik site. Dominion owns $40 \%$ of the mine; the remainder is held by Rio Tinto, which developed the facility. Aber changed its name to Harry Winston Diamond Company in 2006 after acquiring the venerable jewelry retailer. In 2013, Harry Winston sold its retail division to Swatch, the Swiss-based luxury group, and became Dominion Diamond Company. The same year, the company acquired a majority share in the Ekati mine for $\$ 553$ million. Dominion markets all of its Ekati and Diavik production separately.

In fiscal year 2015, Dominion sold 3.014 million carats of Diavik's production for US\$351.6 million, 
averaging about $\$ 117$ per carat. By the end of 2015 , according to Dominion's annual report, the average per-carat price slipped to $\$ 105$.

Dominion markets most of its Diavik and Ekati production through its sales offices in Antwerp. About $10 \%$ of its production is sold to clients in India (\$30.4 million, against total sales of \$351.6 million for fiscal year 2015). Initially, the mining companies in northern Canada set aside $10 \%$ of their production for local polishing operations (Krawitz, 2014). In 2008 there were six diamond polishing plants in Yellowknife, employing 150 workers ("Diamond cutting and polishing," 2008). By the following year, however, they all had closed, unable to compete with operations in India and China; this resulted in the loss of CAD \$22 million in territorial government investments (Danylchuk, 2011). Attempts to revive a large cutting industry in Yellowknife have not succeeded, and currently there is only one cutting and polishing plant operating (Danylchuk, 2015).

Despite the demise of the local cutting industry, Dominion invested CAD\$600,000 in 2015 in branding Diavik and Ekati diamonds by reviving the CanadaMark, a marketing program that was suspended after the local diamond operations closed. The CanadaMark brand is a mine-to-market custody chain designed to give diamond buyers the assurance that their purchases have been ethically sourced in Canada and processed by approved manufacturers. The diamond manufacturers selected to produce the CanadaMark come from the company's existing customer base in India and Israel, and they are continually audited to ensure sourcing and quality standards. Participating manufacturers offer the CanadaMark diamonds to retail clients who have signed up for the program.

Dominion targets the younger generation through various social media platforms and traditional advertising in print magazines. This age group is very concerned about ethical sourcing, so the chain-of-custody audit is necessary to provide this as well as the assurance that the diamond is truly Canadian.

Dominion hopes CanadaMark diamonds will eventually carry a premium over unbranded diamonds. The company's focus group research indicates that Canadian consumers will pay as much as $10 \%$ more, while buyers in the U.S. and Europe are willing to pay an additional $4 \%$ to $5 \%$. Chinese buyers, however, noted they were unwilling to pay any premium based on country of origin (B. Bell and J. Pounds, pers. comms., 2015).

\section{STUDIES OF THE DIAMONDS}

Donnelly et al. (2007) presented results from a study of 100 inclusion-bearing Diavik diamonds that had been selected from more than 10,000 carats of "run of mine" production. They found that $83 \%$ of the diamonds were derived from peridotitic mantle source rocks, with Mg-chromite and olivine by far the most common mineral inclusions. Van Rythoven and Schulze (2009) examined inclusions and crystal morphology in a group of 110 Diavik diamonds. They also concluded that the majority were peridotitic, and that multiple growth and resorption events had affected diamonds from the A154 South pipe.

To further characterize the production from Diavik, in 2015 GIA acquired over 777 carats from Dominion Diamond. Of these, nearly 500 carats (326 samples) were gem-quality single-crystal diamonds, with the remainder consisting of bort, which was not part of this study. The 326 gem-quality rough diamonds ranged from 1.20 to $1.80 \mathrm{ct}$, and mainly included D-to-Z range (236), brown (70), yellow (3), gray (16), and pinkish (1) colors (figure 24). Several of the diamonds contained dark-colored inclusions that were assumed to be sulfides and other minerals (figure 25). Since both studies mentioned above were concerned with the inclusions in Diavik diamonds, we decided to focus our characterization on different aspects of the diamonds. Each of the 326 gem-quality diamonds was evaluated for crystal morphology, DiamondView fluorescence, and absorption spectra (FTIR and UV-Vis-NIR).

The Diavik rough diamonds examined were dominated by octahedral forms with varying amounts of resorption (figure 26). Of the 326 samples examined, 63\% (206 diamonds) showed well-developed octahedral forms with little or no resorption toward the dodecahedral form. Twenty stones were very strongly resorbed to dodecahedral forms. Two showed cube forms, and 14 others appeared to be resorbed cubes that resulted in "hopper" forms. The shapes of $22 \mathrm{di}$ amonds were dominated by twinning, with 17 of those being macles. Irregular forms were observed in 43 diamonds, and an additional 19 samples showed octahedral forms but had a complete or partial coating of light or dark fibrous diamond around a gemquality interior (figure 27). Many of the rough octahedral diamonds without a coating showed strongly etched crystal surfaces, similar to those seen beneath the fibrous layer on the coated diamonds (where the coating was broken off), suggesting that a much larger proportion of Diavik rough diamonds was coated at one time. 


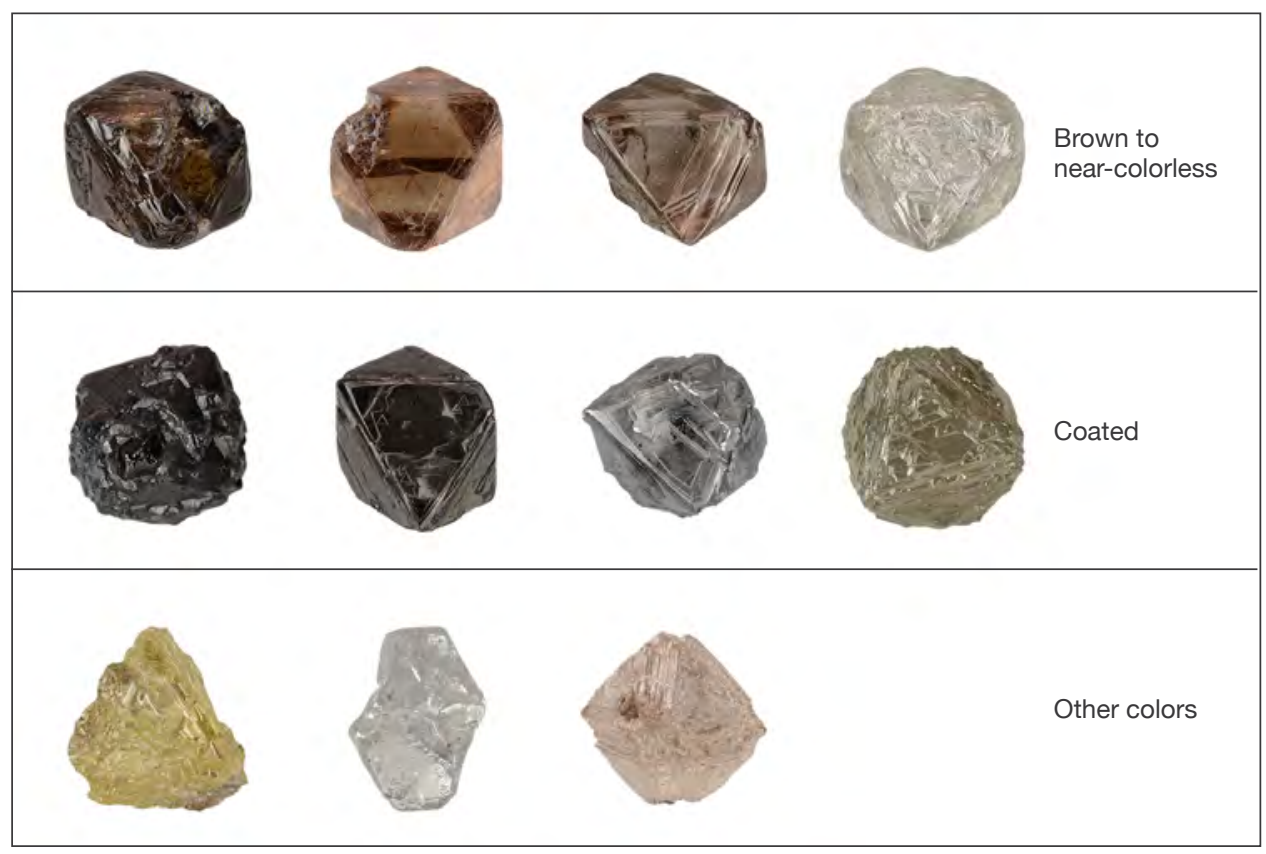

Figure 24. Representative colors of Diavik rough diamonds, ranging from colorless to brown to yellow with one pink crystal. Also shown are several coated crystals. Photos by Jian Xin (Jae) Liao.

DiamondView imaging revealed uniform blue fluorescence in about $98 \%$ of the samples, varying in intensity from very weak to strong (figure 28). Only seven diamonds showed predominantly green fluorescence, all of which had resorbed cube-form "hopper" shapes. Three samples showed isolated patches of

Figure 25. Several of the Diavik diamonds exhibited dark inclusions, presumably sulfide minerals. Photos by Jian Xin (Jae) Liao.

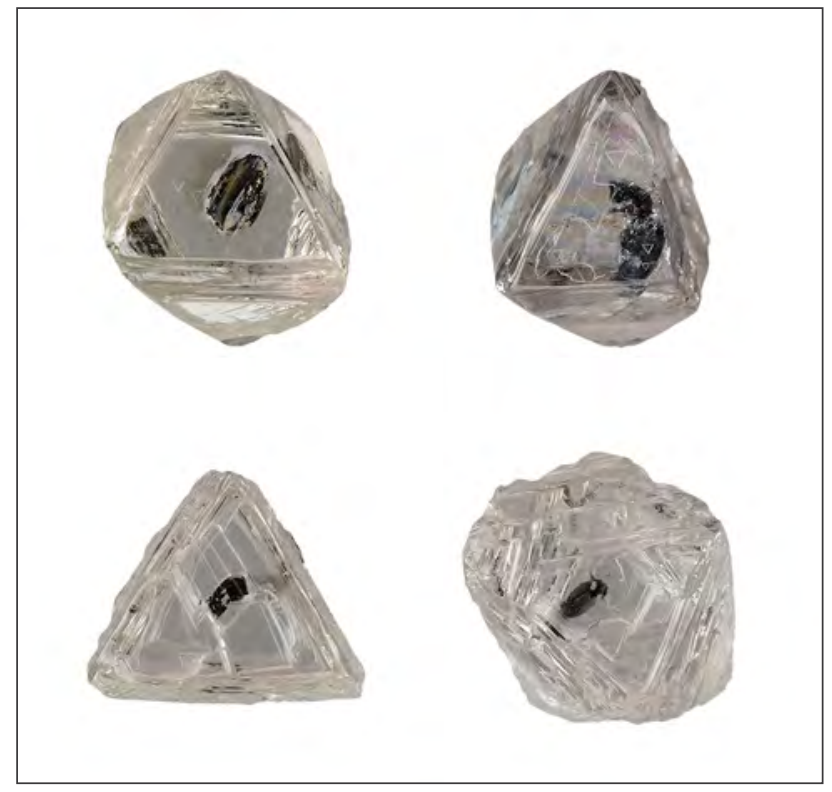

green fluorescence from the $\mathrm{H} 3$ optical defect oriented along crisscrossing linear planes within the dominant blue. The coated samples showed blue fluorescence in both the gemmy interior and the fibrous coating.

Infrared absorption spectra, collected using a Thermo Nicolet 6700 spectrometer with a diffuse reflectance accessory, revealed that all of the diamonds in this study contained nitrogen impurities and were type Ia. Total nitrogen content ranged from approximately 6 ppm to more than 1000 ppm, with only eight samples containing less than 100 ppm. Nearly $98 \%$ of the samples were either pure type IaA /dominated by A-aggregate nitrogen pairs) or mixed IaAB types with various proportions of A- and B-aggregates. Only eight (less than $3 \%$ ) were pure type IaB (dominated by B-aggregate nitrogen groups), suggesting that the Diavik diamonds had not spent a long enough residence time at elevated temperatures within the earth for advanced nitrogen aggregation to occur (Allen and Evans, 1981).

UV-visible absorption spectra were collected at liquid nitrogen temperature using an Ocean Optics CCD spectrometer, integrating sphere, and halogen light source to evaluate the cause of color in the Diavik diamonds. Four UV-Vis spectral features were recorded: "cape" bands at 415 and 478 nm /causing pale yellow color), "vacancy cluster" general absorption increasing to shorter wavelengths /causing brown color), "550 nm" broad band absorption associated with plastic deformation (causes brown or pink color), and broad hydrogen-related bands at ap- 


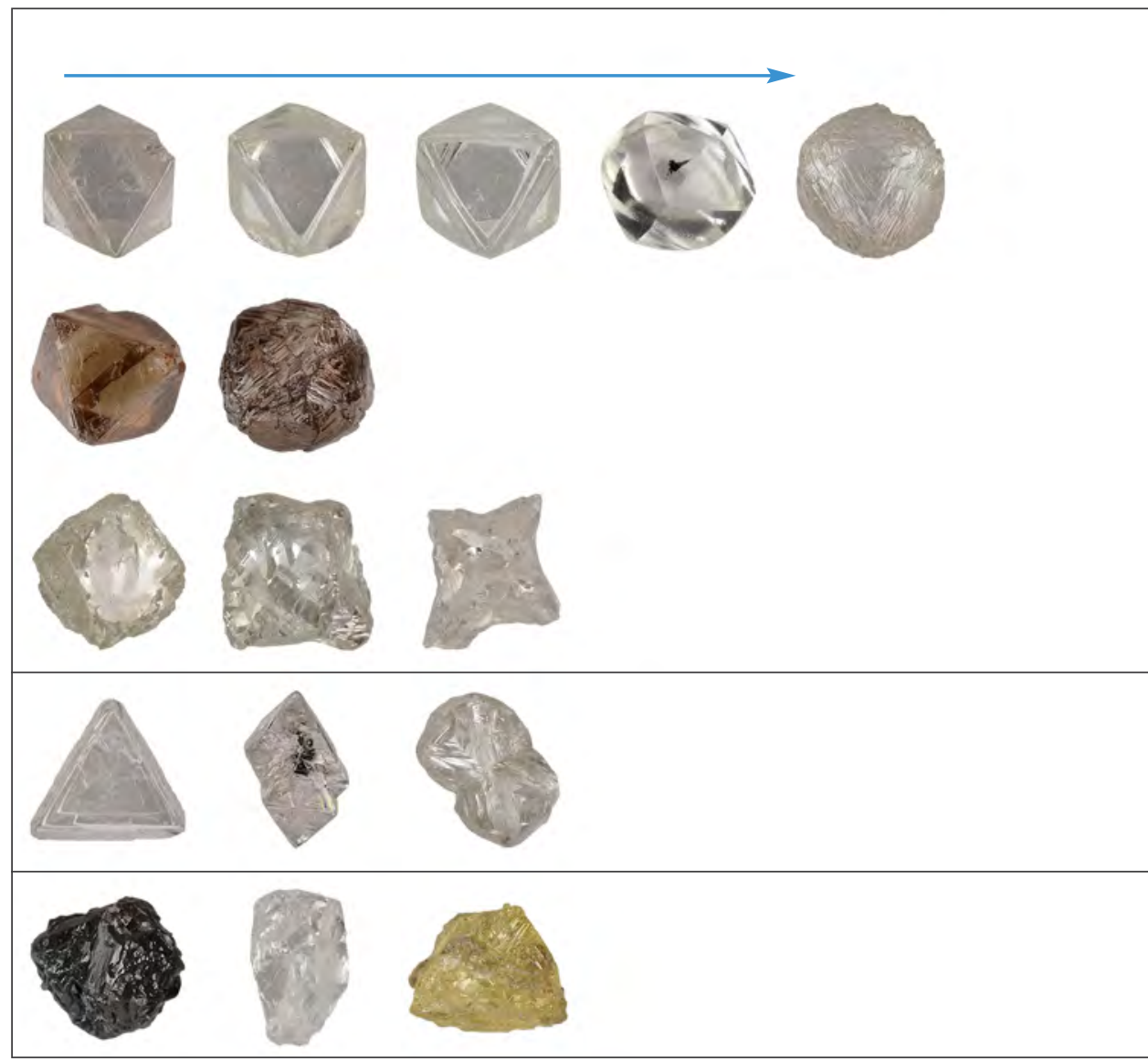

Figure 26. The morphology of the Diavik diamonds was dominated by octahedral forms that displayed varying amounts of resorption. Cube, twinned, and irregular forms were also present. Photos by Jian Xin (Jae) Liao.

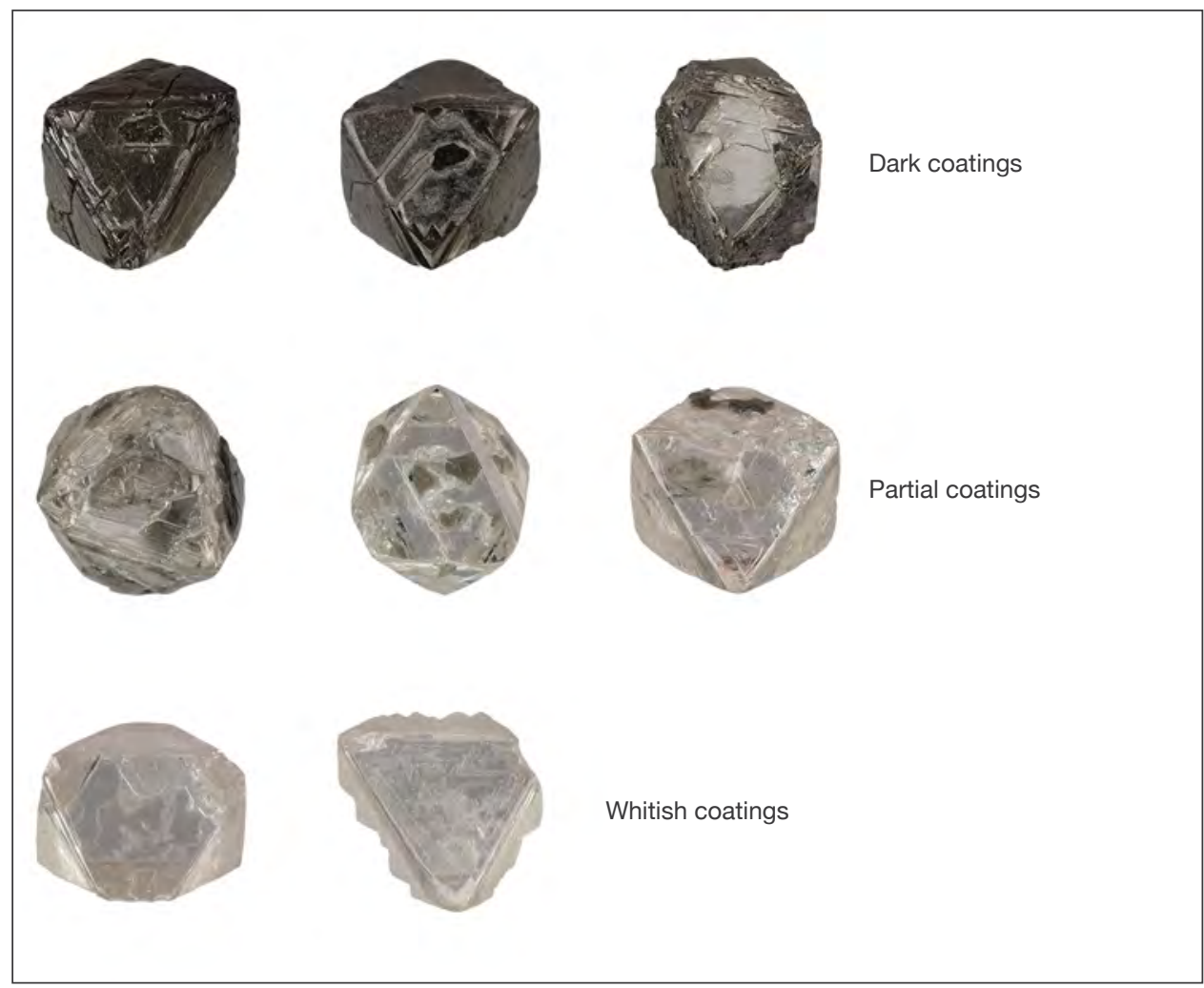

Figure 27. Dark- and light-colored fibrous diamond coatings were observed on a few of the crystals. Photos by Jian Xin (Jae) Liao. 

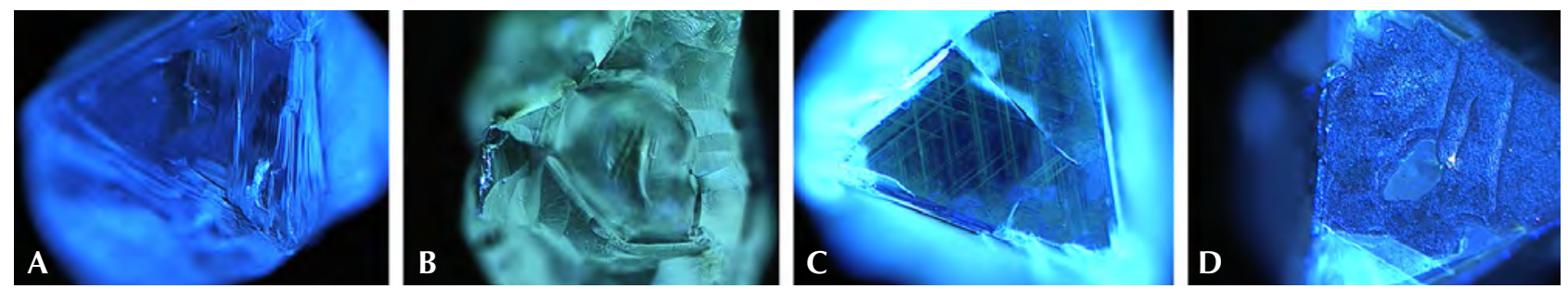

Figure 28. DiamondView imaging showed mostly uniform blue fluorescence (A). Seven "hopper"-form diamonds showed predominantly green fluorescence (B), and a few crystals showed green luminescence from H3 optical defects in linear patterns (C). Both fibrous coatings and interiors of coated diamonds (where parts of the coating are missing) fluoresced blue (D). Images by Kyaw Soe Moe.

proximately 720 and $840 \mathrm{~nm}$ (causes brownish or greenish color) (figure 29). Based on the spectra, 58\% of the rough diamonds have yellowish D-to-Z range or brighter yellow colors produced by "cape" bands with or without hydrogen features. With the exception of one pink diamond colored by a $550 \mathrm{~nm}$ band and 16 gray stones colored by coatings, the remaining samples were various shades of brown caused by a combination of vacancy cluster and $550 \mathrm{~nm}$ band absorptions. The presence of these latter absorption bands in $\sim 37 \%$ of the samples suggests that a significant portion of the Diavik diamonds underwent plastic deformation, likely during kimberlite emplacement and eruption.

Figure 29. UV-Vis-NIR absorption spectra (offset for clarity) showed four features affecting the Diavik diamonds' color: absorptions due to cape bands, vacancy clusters, the $550 \mathrm{~nm}$ broad band, and hydrogen-related defects.

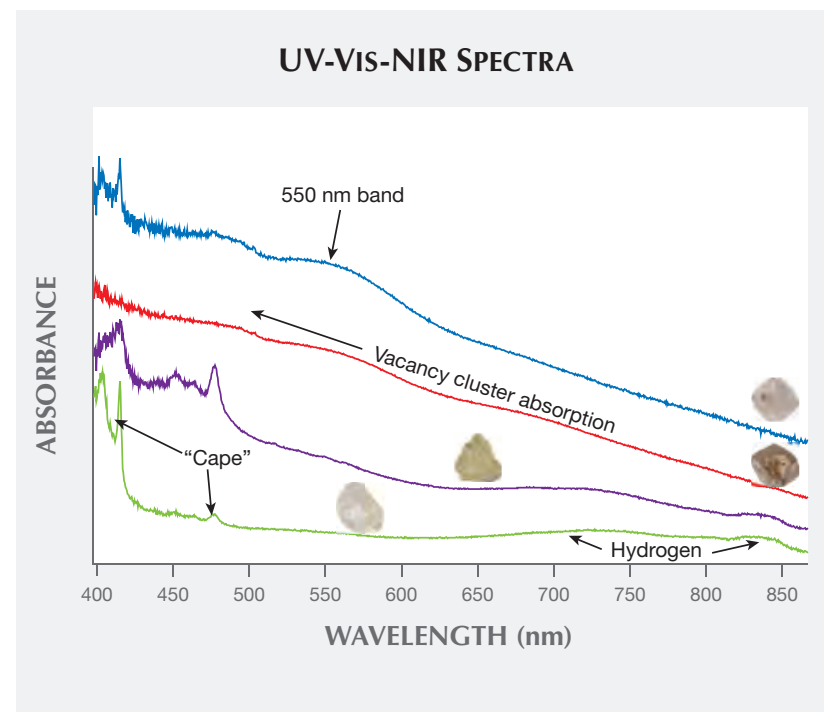

\section{SUMMARY}

Diavik is one of the world's most modern diamond mining operations. It is the largest diamond mine in Canada, producing approximately seven million carats per year, divided between the two owners. In June 2016, Diavik surpassed 100 million carats of production ("Diavik diamond mine: 2015 sustainable development report," 2016). Construction and operation of the mine presented considerable challenges because of Diavik's setting in an extremely remote

Figure 30. The superior quality of Diavik's production will ensure profitability through 2024. Photo courtesy of Rio Tinto Diamonds.

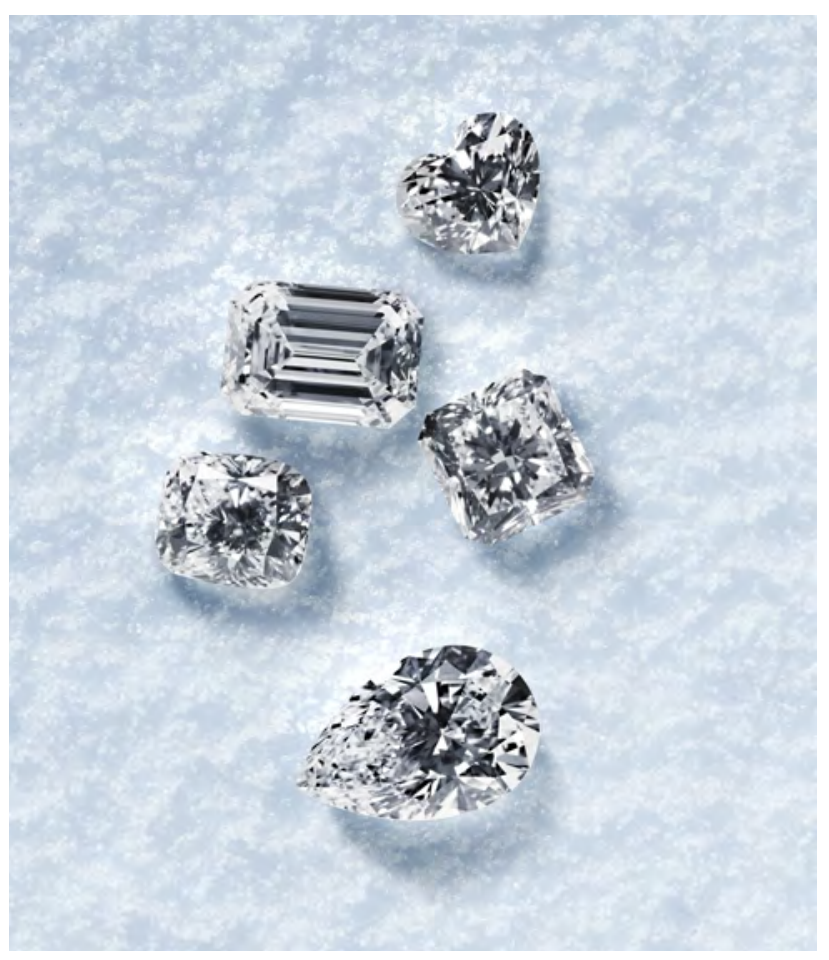


arctic area that can only be supplied for eight weeks a year via a temporary ice road. The kimberlite pipes are also located under lakes, requiring an elaborate system of dikes and drainage to maintain safe mining operations. While the mine is costly to run safely and sustainably, the high quality of the diamonds it produces (figure 30) will enable it to operate at a profit until its scheduled closing in 2024.

\section{ABOUT THE AUTHORS}

Dr. Shigley is distinguished research fellow, Mr. Shor is senior industry analyst, Mr. Padua is a video producer, and Dr. Breeding is a senior research scientist at GIA in Carlsbad, California. Dr. Shirey is a senior scientist in the Department of Terrestrial Magnetism of the Carnegie Institution in Washington DC. Mr. Ashbury is the communications advisor for the Diavik mine.

\section{ACKNOWLEDGMENTS}

The GIA authors thank the management of the Diavik mine for the opportunity to visit the site in June 2015 to gather photographs and document the mining, processing, and sorting operations. Warren Boyd (Potentate Mining, LLC) Brendan Bell and James Pounds (Dominion Diamond Corporation), and Robyn Ellison (Rio TInto Diamonds) are thanked for their comments for the article.

\section{REFERENCES}

Allen B.P., Evans T. (1981) Aggregation of nitrogen in diamond, including platelet formation. Proceedings of the Royal Society of London A, Vol. 375, No. 1760, pp. 93-104, http://dx.doi.org/ 10.1098/rspa.1981.0041

Aulbach S., Stachel T., Creaser R.A., Heaman L.M., Shirey S.B., Muehlenbachs K., Eichenberg D., Harris J.W. (2009) Sulphide survival and diamond genesis during formation and evolution of Archaean subcontinental lithosphere: A comparison between the Slave and Kaapvaal cratons. Lithos, Vol. 112, Supp. 2, pp. 747-757, http://dx.doi.org/10.1016/j.lithos.2009.03.048

Bell R. (1906) The occurrence of diamonds in the drift of some northern states. Journal of the Canadian Mining Institute, Vol. 9, pp. 124-127.

Bleeker W. (2002) Archaean tectonics: A review, with illustrations from the Slave craton. Geological Society of London Special Paper, Vol. 199, pp. 151-181, http://dx.doi.org/10.1144/GSL.SP. 2002.199.01.09

Boyd W.E. (2006) Canadian diamonds - Obscurity to center stage. Rocks \& Minerals, Vol. 81, No. 4, pp. 278-283, http://dx.doi.org/10.3200/RMIN.81.4.278-283

Braden B. (2011) On Good Ice: The Evolution of Canada's Arctic Ice Road, Lifeline to Gold, Diamonds and the Future. Friesens Ltd., Altona, Canada.

Bryan D., Bonner R. (2003) The Diavik diamond mine, Lac de Gras, Northwest Territories, Canada. In B.A. Kjarsgaard, Ed., Proceedings of the Eighth International Kimberlite Conference, Slave Province and Northern Alberta Field Trip Guidebook, pp. 61-65.

Canil D. (2008) Canada's craton: A bottoms-up view. GSA Today, Vol. 18, No. 6, pp. 4-10, http://dx.doi.org/10.1130/ GSAT01806A.1

Carlson J.A., Kirkley M.B., Thomas E.M., Hillier W.D. (1999) Recent Canadian kimberlite discoveries. In J.J. Gurney, J.L. Gurney, M.D. Pascoe, and S.H. Richardson, Eds., Proceedings of the Seventh International Kimberlite Conference, J.B. Dawson volume, Red Roof Design, Cape Town, pp. 81-89.

Danylchuk J. (2011) Romancing the stones. The Edge, June 1 http://edgeyk.com/article/romancing-the-stones/

Danylchuk J. (2015) Where's Deepak? And where's the gem-cutting industry? The Edge, May 28, http://edgeyk.com/article/ wheres-deepak-and-wheres-the-gem-cutting-industry/
Davis W.J., Jones A.G., Bleeker W., Grütter H. (2003) Lithosphere development in the Slave craton: A linked crustal and mantle perspective. Lithos, Vol. 71, No. 2/4, pp. 575-589, http://dx.doi.org/10.1016/S0024-4937/03/00131-2

Diamond cutting and polishing (2008) Natural Resources Canada, http://www.nrcan.gc.ca/mining-materials/diamonds/industry $/ 8167$

Diavik diamond mine reclamation review \& cost estimate (2007) Brodie Consulting Ltd. West Vancouver. http://www.mvlwb.ca/ Boards/WLWB/Registry/2007/W2007L2-0003/W2007L2 $0003 \%$ 20-\%20Diavik\% 20-\% 20Security \% 20Review\% 20\%202007\%20INAC\%20Estimate\%20-\%20Mar\%2000_07.pdf/

Diavik diamond mine: 2014 sustainable development report (2015) Rio Tinto and Dominion Diamond Corporation, http://www.riotinto.com/documents/Diavik_Diamond_Mine

Diavik diamond mine: 2015 sustainable development report (2016) Rio Tinto and Dominion Diamond Corporation, http://www.riotinto.com/documents/2015_Diavik_Sustainable_Development_report.pdf

Dominion Diamonds second quarter interim report (2014) Sep. 4, http://www.ddcorp.ca/investors/news-single? $\mathrm{id}=1963590$

Donnelly C.L., Stachel T., Creighton S., Muehlenbachs K., Whiteford S. (2007) Diamonds and their mineral inclusions from the A154 south pipe, Diavik Diamond mine, Northwest Territories, Canada. Lithos, Vol. 98, No. 1/4, pp. 160-176, http://dx.doi.org/10.1016/j.lithos.2007.03.003

Fipke C.E., Dummett H.T., Moore R.O., Carlson J.A., Ashley R.M., Gurney J.J., Kirkley M.B. (1995) History of the discovery of diamondiferous kimberlites in the Northwest Territories, Canada. Extended Abstract, Sixth International Kimberlite Conference, Novosibirsk, Russia, pp. 158-160.

Giant headache (2014) The Economist, Sept. 27, www.economist. com/node/21620280/print.

Graham I., Burgess J.L., Bryan D., Ravenscroft P.J., Thomas E., Doyle B.J., Hopkins R., Armstrong K.A. (1999) Exploration history and geology of the Diavik kimberlites, Lac de Gras, Northwest Territories, Canada. In J.J. Gurney, J.L. Gurney, M.D. Pascoe, and S.H. Richardson, Eds., Proceedings of the Seventh International Kimberlite Conference, J.B. Dawson volume, Red Roof Design, Cape Town, pp. 262-279.

Gurney J.J. (1984) A correlation between garnets and diamonds in 
kimberlites. In J.E. Glover and P.G. Harris, Eds., Kimberlite Occurrence and Origin: A Basis for Conceptual Models in Exploration, Publication 8. University of Western Australia Geology Department, Perth, pp. 143-166.

Hausel W.D. (1995) Diamonds and their host rocks in the United States. Mining Engineering, Vol. 47, No. 8, pp. 723-732.

Helmstaedt H. (2009) Crust-mantle coupling revisited: The Archean Slave craton, NWT, Canada. Lithos, Vol. 112, Supp. 2, pp. 1055-1068, http://dx.doi.org/10.1016/j.lithos.2009.04.046

Hobbs W.H. (1899) The diamond field of the Great Lakes. Journal of Geology, Vol. 7, No. 4, pp. 375-388, http://dx.doi.org/10.1086/ 608388

Janse A.J.A. (2007) Global rough diamond production since 1870. GÆ G, Vol. 43, No. 2, pp. 98-119, http://dx.doi.org/10.5741/ GEMS.43.2.98

Jones A.G., Lezaeta P., Ferguson I.J., Chave A.D., Evans R.L., Garcia X., Spratt J. (2003) The electrical structure of the Slave craton. Lithos, Vol. 71, No. 2/4, pp. 505-527, http://dx.doi.org/10.1016/ j.lithos.2003.08.001

Kjarsgaard B.A., Levinson A.A. (2002) Diamonds in Canada. $G \uplus G$, Vol. 38, No. 3, pp. 208-238, http://dx.doi.org/10.5741/GEMS. 38.3.208

Krajick K. (1994) The great Canadian diamond rush. Discover, Vol. 15 , No. 12 , pp. $70-79$.

Krajick K. (2001) Barren Lands. Henry Holt and Company, New York, $442 \mathrm{pp}$.

Krawitz A. (2014) Dominion Diamond Corp. to launch contract sales in July. Diamonds.net, June 2, http://www.diamonds. net/News/PrintArticle.aspx? ArticleID $=47080 \&$ ShowArticle $=$ MTn0\%2fxnlXtf11S3dsQYMPBT2a1aPTNXp

Krawitz A. (2015) Rio Tinto publishes 17 select diamantaires for 2015. Diamonds.net, Jan. 26, http://www.diamonds.net/News/ NewsItem. aspx? ArticleID $=50188 \&$ ArticleTitle=Rio+Tinto + Publishes+17+Select+Diamantaires+for+2015

McClenaghan M.B. (2005) Indicator mineral methods in mineral exploration. Geochemistry: Exploration, Environment, Analysis, Vol. 5, No. 3, pp. 233-245, http://dx.doi.org/10.1144/14677873/03-066

McClenaghan M.B., Kjarsgaard B.A. (2001) Indicator mineral and geochemical methods for diamond exploration in glaciated terrain in Canada. In M.B. McClenaghan, P.T. Bobrowsky, G.E.M. Hall, and S.J. Cook, Eds., Drift Exploration in Glaciated Terrain, Geological Society of London Special Paper, Vol. 185, pp.
$83-123$

McClenaghan M.B., Thorleifson L.H., DiLabio R.N.W. (2000) Till geochemical and indicator mineral methods in mineral exploration. Ore Geology Reviews, Vol. 16, No. 3/4, pp. 145-166, http://dx.doi.org/10.1016/S0169-1368(99)00028-1

Moss S., Russell J.K., Andrews G.D.M. (2008) Progressive infilling of a kimberlite pipe at Diavik, Northwest Territories, Canada: Insights from volcanic facies architecture, textures, and granulometry. Journal of Volcanology and Geothermal Research, Vol. 174, No. 1/3, pp. 103-116, http://dx.doi.org/10.1016/j.jvolgeores.2007.12.020

Olive R., Wonnacott J., Schwank S. (2004) Dykes to access Canadian diamonds: The Diavik experience. ANCOLD Bulletin, No. 126 , pp. 147-155

Pell J.A. (1995) Kimberlites in the Slave Structural Province, Northwest Territories, Canada: A preliminary review. Extended Abstract, Sixth International Kimberlite Conference, Novosibirsk, Russia, pp. 433-435.

Pell J.A. (1997) Kimberlites in the Slave craton, Northwest Territories, Canada. Geoscience Canada, Vol. 24, No. 2, pp. 77-90.

Shirey S.B., Shigley J.E. (2013) Recent advances in understanding the geology of diamonds. $G \uplus G$, Vol. 49, No. 4, pp. 188-222, http://dx.doi.org/10.5741/GEMS.49.4.188

Tupper L.E., Neamtz S.E. (2002) Diavik: Our Foundation, Our Future: The Story of the Diavik Diamonds Project. Diavik Diamond Mines, $67 \mathrm{pp}$.

Van Rythoven A.D., Schulze D.J. (2009) In-situ analysis of diamonds and their inclusions from the Diavik mine, Northwest Territories, Canada: Mapping diamond growth. Lithos, Vol. 112, Supp. 2, pp. 870-879, http://dx.doi.org/10.1016/j.lithos.2009.04.025

Weiss Y., McNeill J., Pearson G., Nowell G.M., Ottley C.J. (2015) Highly saline fluids from a subducting slab as the source of fluid-rich diamonds. Nature, Vol. 524, No. 7565, pp. 339-342, http://dx.doi.org/10.1038/nature14857

Westerlund K.J., Shirey S.B., Richardson S.H., Carlson R.W., Gurney J.J., Harris J.W. (2006) A subduction wedge origin for Paleoarchean peridotitic diamonds and harzburgites from the Panda kimberlite, Slave craton: Evidence from Re-Os isotope systematics. Contributions to Mineralogy and Petrology, Vol. 152, No 3, pp. 275-294, http://dx.doi.org/10.1007/s00410-006-0101-8

Yip C.G., Thompson K.S. (2015) Diavik Diamond Mine, Northwest Territories, Canada - NI 43-101 Technical Report $(25$ March 2015), 128 pp.

\section{For More on the Diavik Diamond Mine}

To learn more about Canada's Diavik mine, visit www.gia.edu/gems gemology/summer 2016 diamonds canadian arctic diavik mine, or scan the QR code on the right.
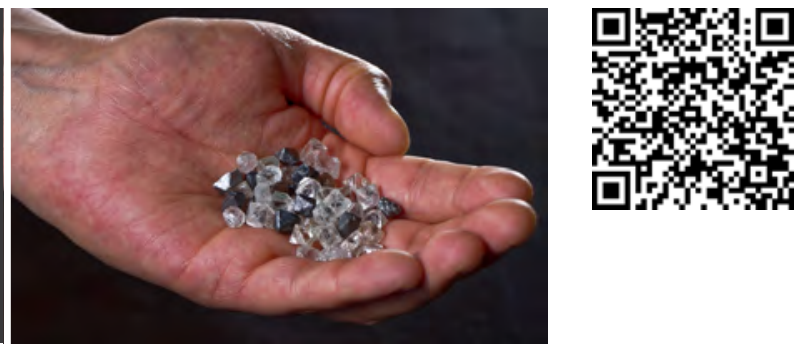